\title{
Gold deposits in Chile
}

\author{
José Cabello ${ }^{1}$ \\ ${ }^{1}$ Mineralium Consulting Group, Escritor Manuel Rojas 1699-D, La Reina, Santiago, Chile. \\ cabello.lechuga@vtr.net
}

\begin{abstract}
A review of gold and gold bearing base metals deposits in Chile, indicate the existence of at least six different type of ore deposits, most largely formed during the Cenozoic with predominance in the Miocene. Mesozoic deposits are common but less relevant regarding their size and gold content. These hydrothermal ore deposits are genetically associated with subduction related Andean arc magmatism. Due to its relationship with episodic magmatism migrating eastward, there is a tendency for the deposits to be in distinct, north-south trending, belts with a progressive west to east decrease in mineralization age. After analysing 82 cases in total, main gold concentration can be assigned to high-sulfidation epithermal and porphyry type deposits. Low-sulfidation epithermal, IOCG and mesothermal type appears as less relevant. Gold bearing copper deposits constitute an important part of Chile's total gold production. Both IOCG type but especially porphyry copper deposits are and will remain as a substantial source to supplement the future output of the gold in the country. The 82 deposits with their tonnage and grade studied, represent a total gold content of 11,662 t equivalent to $375 \mathrm{Moz}$, excluding past production for those exploited. A number of probable gold bearing base metals high tonnage deposits (IOCG and porphyry copper) do not include their gold content in public format, hence the number delivered could be estimated conservative. Methodical geochronological, ore types and zonation studies are required to better appreciate this metallogenic setting widening current understanding and future exploration results.
\end{abstract}

Keywords: Andean magmatism, Gold deposits belts, Ore deposit type, Tonnage and grade.

RESUMEN. Yacimientos de oro en Chile. Una revisión de yacimientos de oro y de metales básicos con oro, indican la existencia de por lo menos seis diferentes tipos de yacimientos, mayormente formados durante el Cenozoico con predominancia en el Mioceno. Los depósitos de edad mesozoica son de ocurrencia frecuente, pero menos relevantes en cuanto a tamaño y contenido de oro. Estos yacimientos hidrotermales están genéticamente vinculados con arcos magmáticos andinos, de orientación norte-sur, asociados a subducción. Debido a su relación con un magmatismo episódico migrante hacia el este, los yacimientos presentan una tendencia a distribuirse en diferentes franjas de orientación meridional, con una progresiva disminución de la edad de la mineralización hacia el este. Del análisis de un total de 82 yacimientos, la principal concentración de oro puede asignarse a depósitos tipo epitermal de alta sulfuración, pórfidos aurífero y pórfidos de cobre. Los yacimientos tipo epitermal de baja sulfuración, IOCG y mesotermal aparecen como menos importantes. Yacimientos cupríferos con mineralización aurífera subordinada constituyen una importante parte del total de la producción de oro en Chile. Los yacimientos tipo IOCG, y sobre todo los pórfidos cupríferos son y permanecerán como importantes recursos para contribuir a la futura producción de oro en el país. Los 82 depósitos con tonelaje y ley estudiados, representan un total de $11.662 \mathrm{t}$ de oro contenido equivalente a 375 Millones de onzas excluyendo la producción pasada para los yacimientos que han sido explotados. Sin embargo, un número importante de yacimientos con gran tonelaje de metales básicos con oro subordinado (IOCG y pórfidos cupríferos) no publican su contenido de oro, por lo que las cifras acá entregadas podrían ser consideradas conservadoras. Estudios sistemáticos de geocronología, tipos de yacimientos y zonación, son necesarios para ampliar su entendimiento metalogénico, así como futuros resultados en exploración. 


\section{Introduction}

Chile produced 38 tonnes of gold in 2019 making it the $21^{\text {th }}$ most important gold miner in the world and the fifth in South America after Perú, Brazil, Argentina and Colombia (Sernageomín, 2020). Annual production should increase further as a result of proposed new developments at the Pascua and Cerro Casale projects where annual productions of $20 \mathrm{t}$ and $7.7 \mathrm{t}$ respectively have been projected.

Even if gold production exists from pre-Hispanic times, recognition of Chile as an important gold province (Fig. 1) is in part the result of exploration successes in the last five decades (Sillitoe, 1995, 2000, 2010; Cabello, 1999, 2002).

Although in detail more complex, the geology of the Chilean Andes can be interpreted as a sequence of eastward migrating Mesozoic and Cenozoic magmatic arcs built over Paleozoic and Precambrian basement (Hervé et al., 2007). Hydrothermal gold deposits are more common in northern and central Chile ( $\mathrm{ca} .18^{\circ}-34^{\circ} \mathrm{S}$; Fig. 1) where they are closely related to several discrete magmatic arcs generated during Mesozoic to Miocene time. Gold deposits, in common with the magmatic arcs that contain them are progressively younger eastward (Davidson and Mpodozis, 1991). Several isotopic studies indicate a general trend of increasing crustal contamination throughout the Cenozoic arc evolution (Miller and Harris, 1989), but apparently there is no influence in the magmatism related to gold mineralization of the same age (Sillitoe, 1991).

The most important gold deposits are of epithermal and porphyry type (Table 1). Mesothermal, skarn, or stratabound are less prominent. Placer type gold deposits, common in central-southern Chile, realized important production from 1541 to the end of the sixteenth century (Cuadra and Dunkerley, 1991). Gold-bearing copper deposits have contributed an important component to Chile's total gold production (today about 50\%). IOCG type deposits and especially porphyry coppers are and will remain significant sources of gold production (Table 2 and 3). All-important gold bearing base metals deposits are Mesozoic or Cenozoic in age (Maksaev et al., 2007).

This article intends to update the knowledge originated previously by different authors (Ruiz and Peebles, 1988; Camus, 1990; Sillitoe, 1991; Cabello, 1992; Kojima, 1999; Maksaev et al., 2007), including information about deposits that were less known or unknown in the previous century.

\section{Geological setting}

The Andes of Chile are the southernmost part of the Cordilleran igneous and tectonic region that is continuous along the western margins of the North and South American plates from Alaska to Chile (Davidson and Mpodozis, 1991; Charrier et al., 2007). This margin of South America has faced the Pacific Ocean throughout the Phanerozoic and has been a convergent plate margin since late Paleozoic.

The magmatic and tectonic evolution of the Chilean Andes has been the subject of several studies (e.g., Mpodozis and Ramos, 1990; Kay et al., 1999; Charrier et al., 2007; Parada et al., 2007). Although exceptionally broad and geologically complex, the Chilean sector of the Andes can be interpreted as a sequence eastward-migrating Mesozoic and Cenozoic magmatic arcs (Coira et al., 1982; Stern, 2004; Mpodozis and Cornejo, 2019), built over Paleozoic and Precambrian basement. These arcs were formed by active subduction of the oceanic plate beneath the South American plate at least since Paleozoic times. The pre-Jurassic basement is made up of a collage of discrete fragments of Precambrian to early Paleozoic allocthonous or displaced terranes belonging to the Gondwana Continent (e.g., Oliveros et al., 2020). Existing geologic provinces owe their distribution to segmentation of the subducted Nazca plate (Jordan et al., 1983; Tassara et al., 2006; Bloch et al., 2018).

An early Carboniferous magmatic arc appears to have been established over Precambrian and early Paleozoic rocks along the length of the Chilean Andes (Coloma et al., 2017). This arc was bounded by an accretionary prism oceanward and by a foreland sedimentary basin toward the continental interior (Willner et al., 2009; Deckart et al., 2014). Calc-alkaline, mantle-derived granitoids of late Carboniferous ages are well exposed in parts of central-northern Chile (Nasi et al., 1985; Charrier et al., 2014). A large Permian to Triassic silicic volcanic field and associated shallow-level plutons generated by crustal melting in an extensional setting overlies and intrudes the Carboniferous arc (Mpodozis and Kay, 1990; Ramos and Folguera, 2016).

In contrast to the Paleozoic, the MesozoicCenozoic Andes lack evidence of major terrane collisions (Dalziel, 1986; Forsythe et al., 1987). 


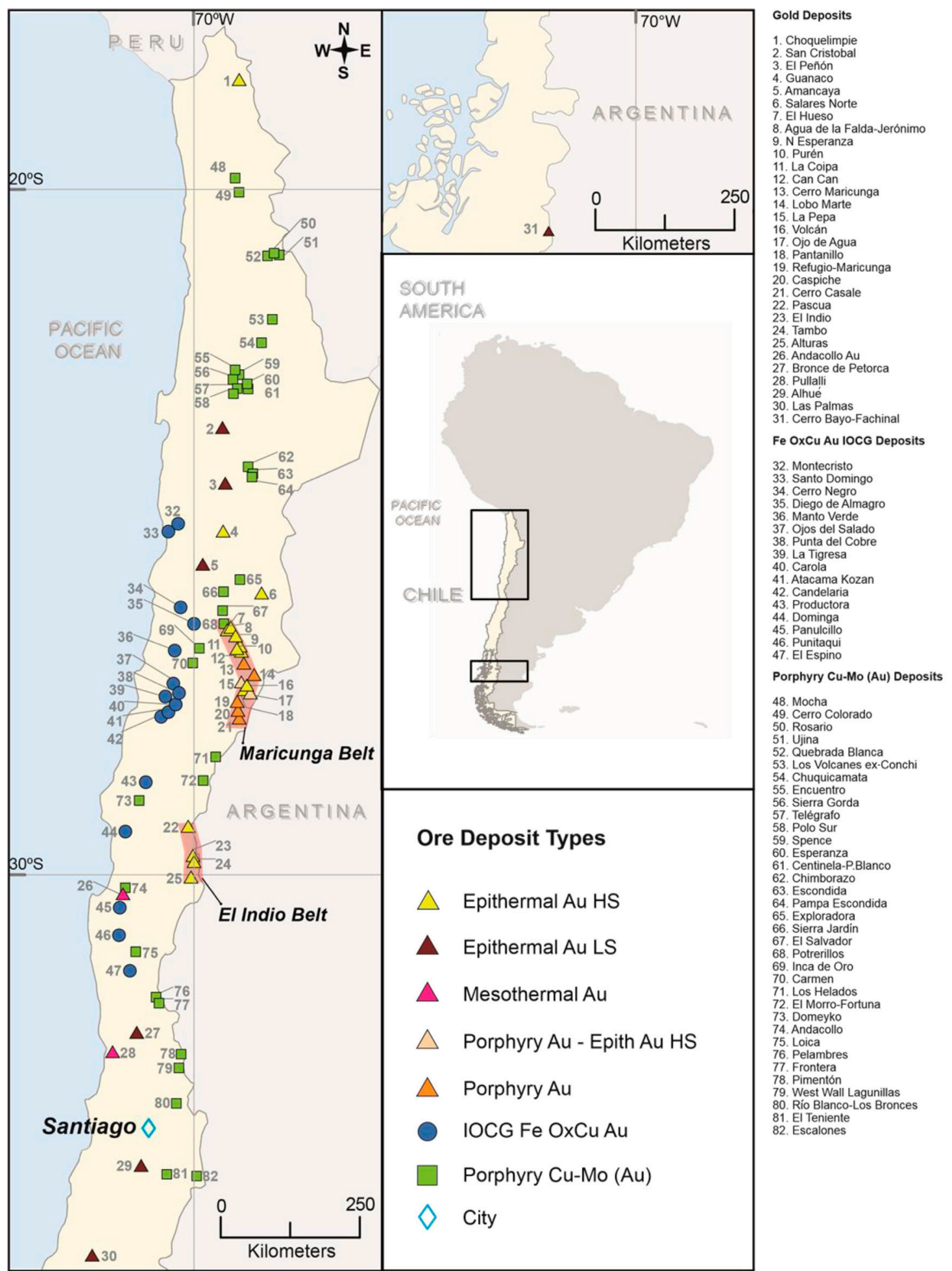

Fig.1. Distribution of the main gold deposits and other important gold bearing ore deposits type in Chile. 
TABLE 1. MAIN GOLD DEPOSITS IN CHILE.

\begin{tabular}{|c|c|c|c|c|c|c|c|c|}
\hline Name & $\begin{array}{c}\text { Deposit } \\
\text { Type }\end{array}$ & $\begin{array}{c}\text { Ore M } \\
\text { Tons }\end{array}$ & Au gt & Ag gt & T Au & $\begin{array}{c}\mathrm{M} \mathrm{Oz} \\
\mathrm{Au}\end{array}$ & Age & References \\
\hline Choquelimpie & EpithAu HS & 11.00 & 2.23 & 60 & 24.53 & 0.79 & Miocene & Sillitoe, 1999 \\
\hline San Cristóbal & EpithAu LS & 25.00 & 0.90 & 3 & 22.50 & 0.72 & $\begin{array}{l}\text { Paleocene- } \\
\text { Eocene }\end{array}$ & Cabello, 2002 \\
\hline El Peñón & EpithAu LS & 32.40 & 8.20 & 249 & 265.68 & 8.54 & $\begin{array}{l}\text { Paleocene- } \\
\text { Eocene }\end{array}$ & Zuluaga, 2018 \\
\hline Guanaco & EpithAu HS & 28.00 & 1.43 & 6 & 40.40 & 1.29 & $\begin{array}{l}\text { Paleocene- } \\
\text { Eocene }\end{array}$ & Nat Res Holdings, 2013 \\
\hline Amancaya & EpithAu LS & 1.40 & 7.90 & 73 & 11.06 & 0.36 & $\begin{array}{l}\text { Paleocene- } \\
\text { Eocene }\end{array}$ & Yamana Gold, 2018 \\
\hline Salares Norte & EpithAu HS & 26.80 & 3.90 & 48.9 & 104.52 & 3.36 & Miocene & Brewer et al., 2017 \\
\hline El Hueso & EpithAu HS & 16.00 & 1.68 & 2 & 26.88 & 0.86 & $\begin{array}{l}\text { Eocene- } \\
\text { Oligocene }\end{array}$ & Cabello, 2002 \\
\hline $\begin{array}{l}\text { Agua de la Falda } \\
\text { Jerónimo }\end{array}$ & EpithAu HS & 16.50 & 6.00 & 3 & 99.00 & 3.18 & $\begin{array}{l}\text { Eocene- } \\
\text { Oligocene }\end{array}$ & Thompson et al., 2004 \\
\hline N Esperanza & EpithAu HS & 39.40 & 0.39 & 66 & 15.37 & 0.49 & Miocene & Kingsgate, 2016 \\
\hline Purén & EpithAu HS & 17.00 & 0.90 & 278 & 15.30 & 0.49 & Miocene & Arribas et al., 2005 \\
\hline La Coipa & EpithAu HS & 88.00 & 0.80 & 84 & 70.40 & 2.26 & Miocene & Cabello, 2002 \\
\hline Can Can & EpithAu HS & 6.00 & 1.30 & na & 7.80 & 0.25 & Miocene & Cabello, 2002 \\
\hline Cerro Maricunga & PorphAu & 474.00 & 0.39 & na & 184.86 & 5.94 & Miocene & Nat. Res. Holdings, 2013 \\
\hline Lobo Marte & PorphAu & 311.00 & 0.98 & na & 304.78 & 9.80 & Miocene & Nat. Res. Holdings, 2013 \\
\hline La Pepa & $\begin{array}{l}\text { Porph Au-Epith } \\
\text { Au HS }\end{array}$ & 187.00 & 0.56 & na & 104.72 & 3.37 & Miocene & Nat. Res. Holdings, 2013 \\
\hline Volcán & EpithAu HS & 431.00 & 0.69 & na & 297.39 & 9.56 & Miocene & Nat. Res. Holdings, 2013 \\
\hline Ojo de Agua & EpithAu HS & 18.60 & 0.85 & na & 15.81 & 0.51 & Miocene & Andina Minerals, 2012 \\
\hline Pantanillo & $\begin{array}{l}\text { Porph Au-Epith } \\
\text { Au HS }\end{array}$ & 47.00 & 0.69 & na & 32.43 & 1.04 & Miocene & Simon et al., 2010 \\
\hline Refugio-Maricunga & PorphAu & 382.00 & 0.66 & na & 252.12 & 8.11 & Miocene & Nat. Res. Holdings, 2013 \\
\hline Caspiche & PorphAu & $1,602.00$ & 0.48 & 1.14 & 768.96 & 24.72 & Miocene & Goldcorp, 2017 \\
\hline Cerro Casale & PorphAu & $1,990.00$ & 0.51 & 1.44 & $1,014.90$ & 32.63 & Miocene & Goldcorp, 2017 \\
\hline Pascua & EpithAu HS & 662.00 & 1.20 & 40 & 794.40 & 25.54 & Miocene & Nat. Res. Holdings, 2013 \\
\hline El Indio & EpithAu HS & 23.20 & 6.60 & 50 & 153.12 & 4.92 & Miocene & Sillitoe, 1999 \\
\hline Tambo & EpithAu HS & 37.00 & 4.10 & na & 151.70 & 4.88 & Miocene & Cabello, 2002 \\
\hline Alturas & EpithAu HS & 211.00 & 1.00 & na & 211.00 & 6.78 & Miocene & Barrick, 2016 \\
\hline Andacollo Au & MesoAu & 253.00 & 0.39 & - & 91.00 & 2.93 & Cretaceous & Slater et al., 2012 \\
\hline Bronce de Petorca & EpithAu LS & 7.60 & 4.60 & 14 & 34.96 & 1.12 & Cretaceous & Camus, 2011 \\
\hline Pullalli & Stratabound & 9.00 & 1.60 & na & 14.30 & 0.46 & Cretaceous & Pegasus Gold Inc., 1997 \\
\hline Alhué & EpithAu LS & 17.00 & 3.60 & na & 61.20 & 1.97 & Cretaceous & Nat. Res. Holdings, 2013 \\
\hline Las Palmas & EpithAu LS & 2.00 & 4.50 & na & 9.00 & 0.29 & Cretaceous & Cabello, 2002 \\
\hline Cerro Bayo-Fachinal & EpithAu LS & 5.90 & 3.30 & 170 & 19.47 & 0.63 & Cretaceous & Poblete, 2011 \\
\hline Subtotal & & & & & $5,227.00$ & 168.03 & & \\
\hline
\end{tabular}

The gold deposits considered are mainly Epithermal ore deposits of high sulfidation (Epithermal HS) and low sulfidation (Epithermal LS), porphyry gold type (Porphyry $\mathrm{Au}$ ) and Mesothermal. Total resources in million tons (Mt) of ore, the ore grade in $\mathrm{g} / \mathrm{t}$ for $\mathrm{Au}$ and $\mathrm{Ag}$, the total Au contained in the deposits is in tons ( $\mathrm{t}$ ) and million ounces (Moz). 
TABLE 2. MAIN IRON OXIDES COPPER GOLD (IOCG) DEPOSITS IN CHILE.

\begin{tabular}{|c|c|c|c|c|c|c|c|c|c|c|}
\hline Name & $\begin{array}{c}\text { Deposit } \\
\text { Type }\end{array}$ & Model & $\begin{array}{l}\text { Ore } \\
\text { Tons }\end{array}$ & $\mathrm{Cu} \%$ & Au gt & T Au & $\begin{array}{c}\mathrm{M} \mathrm{Oz} \\
\mathrm{Au}\end{array}$ & $\begin{array}{l}\text { Age } \\
\text { my }\end{array}$ & Age & References \\
\hline Montecristo & IOCG & $\mathrm{FeOxCuAu}$ & 15 & 1.60 & 0.600 & 9.00 & 0.29 & 164 & Cretaceous & Sillitoe, 2003 \\
\hline Santo Domingo & IOCG & $\mathrm{FeOxCuAu}$ & 485 & 0.32 & 0.043 & 20.86 & 0.67 & - & Cretaceous & Brimage et al., 2011 \\
\hline Cerro Negro & IOCG & $\mathrm{FeOxCuAu}$ & 249 & 0.40 & 0.150 & 37.35 & 1.20 & - & Cretaceous & Atna Resources, 2002 \\
\hline $\begin{array}{l}\text { Diego de } \\
\text { Almagro }\end{array}$ & IOCG & $\mathrm{FeOxCuAu}$ & 70 & 0.65 & 0.050 & 3.50 & 0.11 & $120-100 ?$ & Cretaceous & Herrera et al., 2008 \\
\hline Manto Verde & IOCG & $\mathrm{FeOxCuAu}$ & 440 & 0.56 & 0.120 & 52.80 & 1.70 & $128-117$ & Cretaceous & Richards et al., 2016 \\
\hline Ojos del Salado & IOCG & $\mathrm{FeOxCuAu}$ & 17 & 1.32 & 0.270 & 4.59 & 0.15 & - & Cretaceous & Cabello, 2002 \\
\hline Punta del Cobre & IOCG & $\mathrm{FeOxCuAu}$ & 120 & 1.50 & 0.200 & 24.00 & 0.77 & - & Cretaceous & Sillitoe, 2003 \\
\hline La Tigresa & IOCG & $\mathrm{FeOxCuAu}$ & 8 & 0.56 & 0.270 & 2.16 & 0.07 & - & Cretaceous & Cabello, 2013 \\
\hline Carola & IOCG & $\mathrm{FeOxCuAu}$ & 10 & 1.80 & 0.500 & 5.00 & 0.16 & - & Cretaceous & Vivallo et al., 2008 \\
\hline Atacama Kozan & IOCG & $\mathrm{FeOxCuAu}$ & 50 & 1.60 & 0.350 & 17.50 & 0.56 & - & Cretaceous & Cabello, 2002 \\
\hline Candelaria & IOCG & $\mathrm{FeOxCuAu}$ & 501 & 0.54 & 0.130 & 65.13 & 2.09 & $116-110$ & Cretaceous & Richards et al., 2016 \\
\hline Productora & IOCG & $\mathrm{FeOxCuAu}$ & 214 & 0.48 & 0.100 & 21.40 & 0.69 & $130-128$ & Cretaceous & Marquardt et al., 2015 \\
\hline Dominga & IOCG & $\mathrm{FeOxCuAu}$ & 2 & 0.12 & 0.014 & 28.00 & 0.90 & 127 & Cretaceous & Garrido, 2013 \\
\hline Panulcillo & IOCG & $\mathrm{FeOxCuAu}$ & 15 & 1.45 & 0.100 & 1.50 & 0.05 & 115 & Cretaceous & Chen et al., 2013 \\
\hline Punitaqui & IOCG & $\mathrm{FeOxCuAu}$ & 10 & na & 3.000 & 30.00 & 0.96 & - & Cretaceous & Cabello, 2002 \\
\hline El Espino & IOCG & $\mathrm{FeOxCuAu}$ & 123 & 0.66 & 0.240 & 29.52 & 0.95 & $100-94$ & Cretaceous & López et al., 2014 \\
\hline Subtotal & & & & & & 352.31 & 11.32 & & & \\
\hline
\end{tabular}

Ore resources in million tons $(\mathrm{Mt})$, the ore grade in $\mathrm{g} / \mathrm{t}$ for $\mathrm{Au}$, the total $\mathrm{Au}$ contained in the deposits is in tons (t) and million ounces (Moz).

During Jurassic and early Cretaceous time, the Andean region was characterised by a series of magmatic arcs and back arc basins in a steep-angle subduction regime dominated by back-arc extension and subsidence (Mpodozis and Ramos, 1990; Ramos, 2010), resembling a Mariana-type tectonic setting (Oliveros et al., 2007). From the earliest Mesozoic, huge volumes of calc-alkaline volcanic rocks and related plutons were emplaced along a belt parallel to the present coastline in northern and central Chile. Magmatic rocks from this period represent a welldefined and exposed, linear magmatic arc built over late Paleozoic fore-arc assemblages (Díaz-Alvarado et al., 2019). The arc was bounded to the east by a system of ensialic back-arc basins filled with sediments or thick volcanoclastic successions (Ramos, 2010).

A major middle Cretaceous tectonic break in the Andean evolution occurred between 100 and $88 \mathrm{Ma}$, with the inception of South Atlantic spreading and consequent increase in the westward velocity of the South American plate, a change from lowstress Mariana-type subduction to a compressive subduction system (Chilean type) was produced (Mpodozis and Ramos,1990). This resulted in the closure and collapse of the back arc basins. From this time onward, the calc-alkaline magmatic arc remained as the major tectonic element but a calm in igneous activity occurred in the late Cretaceous (Coira et al., 1982; Charrier et al., 2007).

Intense calc-alkaline magmatism resumed in northern Chile during Paleocene to Eocene times (Charrier et al., 2015). Volcanic centres were displaced eastward with respect to the extinct Jurassic-Early Cretaceous magmatic arc located in the present Coast Range (Charrier et al., 2007). Magmatism ceased in the Eocene as a consequence of the Incaic deformation event, to be followed by a late Eocene-early Oligocene period of relative magmatic quiescence associated with strike-slip faulting (Herrera et al., 2017). A second period of Neogene magmatism began in the late Oligocene when the modern Andean arc was established in the Western Cordillera, even farther east (Jordan and Gardeweg, 1988; Stern, 2004). 


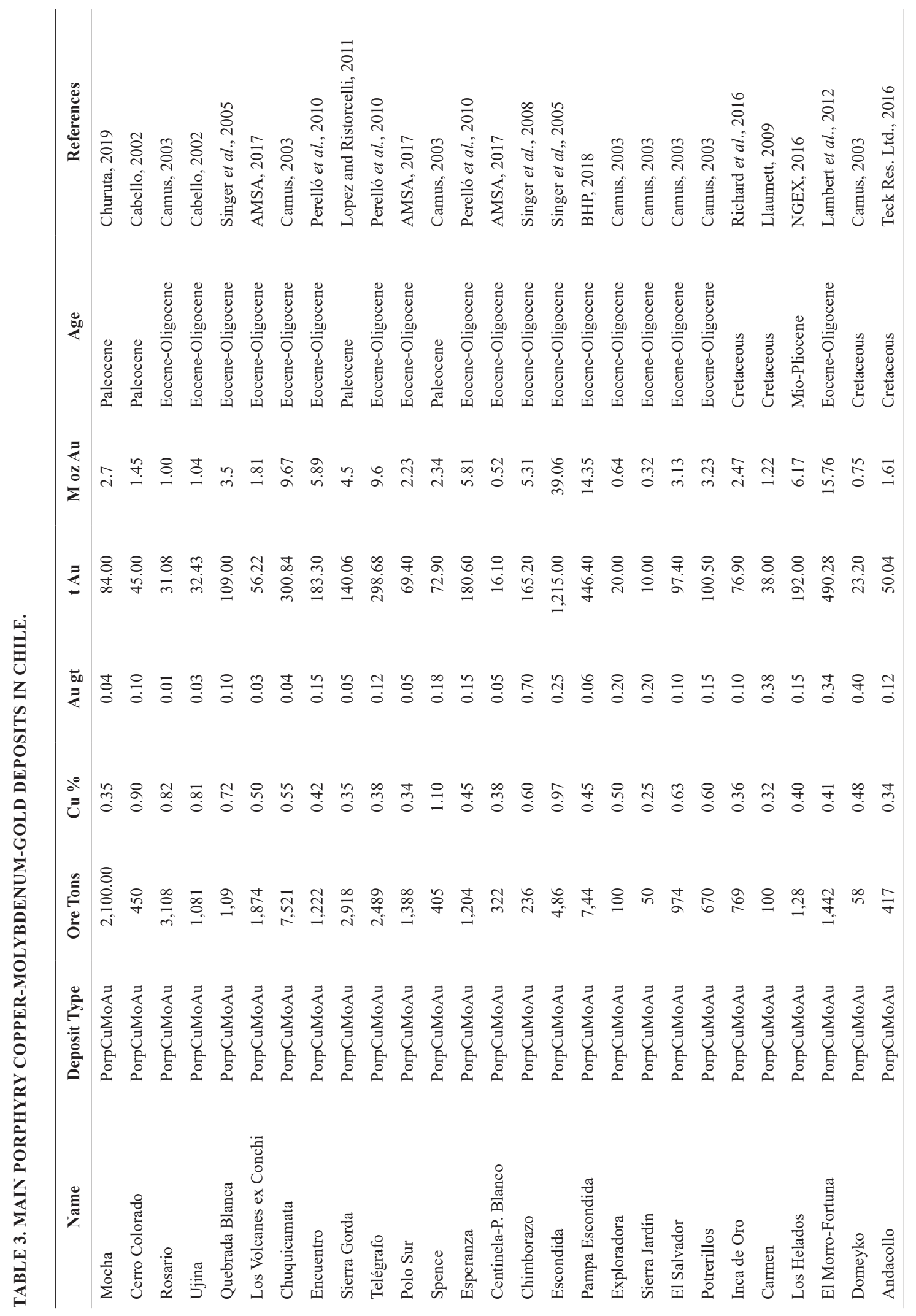




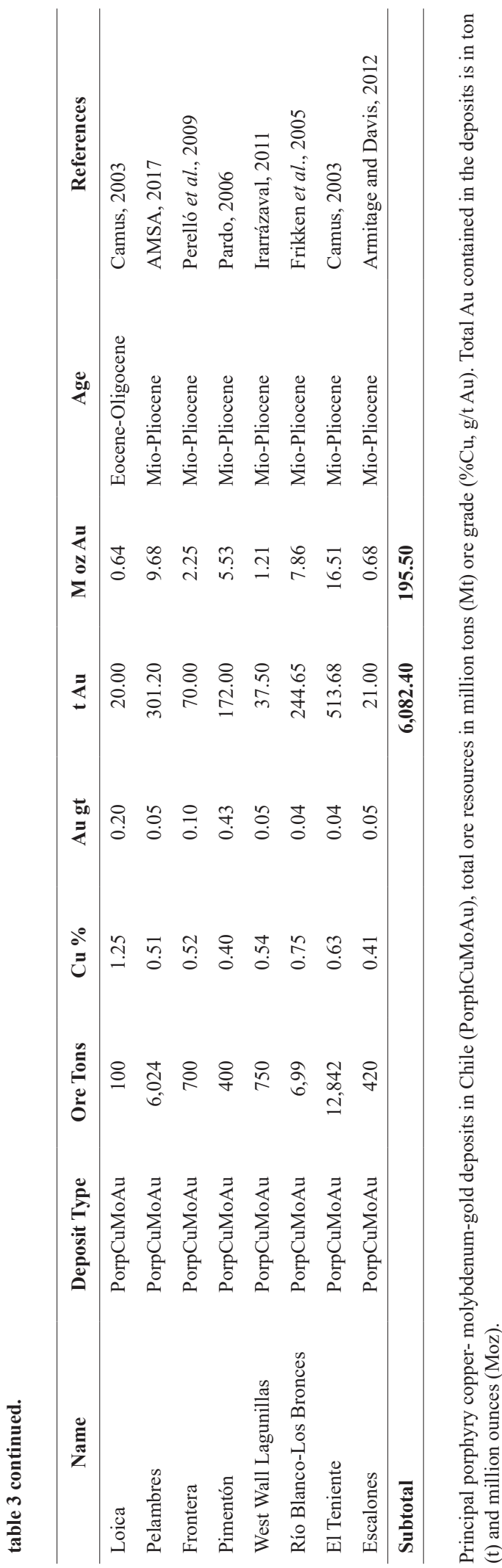

Between $27^{\circ} \mathrm{S}$ and $33^{\circ} \mathrm{S}$, the same PaleoceneEocene magmatic event is recognised, followed by discrete Late Oligocene-Early Miocene, MidMiocene, and Late Miocene magmatic episodes. In this segment of the Andes magmatism ceased in the Late Miocene, when the subduction angle shallowed beneath this region, which today constitutes the nonvolcanic, "flat slab" segment of the Chilean Andes (Kay et al., 1987; Sepúlveda et al., 2015; Ramos and Folguera, 2016).

South of Santiago $\left(33^{\circ} \mathrm{S}\right)$, where the dip of the Benioff zones is again steep $\left(30^{\circ}\right)$ Quaternary volcanism is widespread. No evidence of Paleogene magmatism has been recognized and Miocene volcanics directly overlie the Cretaceous sequences of the main Cordillera, where coeval Miocene granodioritic stocks intrude them (Rivano and Sepúlveda, 1991; Kay and Godoy, 2005).

\section{Hydrothermal gold deposits}

In general, in Chile, main gold producing deposits are hydrothermal (mainly epithermal) polymetallic in a broad geochemical sense with gold content being a minority participant respect to other metals like copper, silver and molybdenum among others. The higher economic value of gold, allow to consider them gold deposits (Kojima and Campos, 2011).

\subsection{Mesozoic gold deposits}

Several gold deposits formed during the Mesozoic time are important today. In the Andacollo mining district (Fig. 1, Table 1), immediately west of the Andacollo porphyry copper, separated by a NS trending normal fault, there are several volcanic hosted gold deposits of manto type and veins. The stratabound mantos located 1 to $3 \mathrm{~km}$ northwest of the Andacollo porphyry copper deposit are considered to be of contact metasomatic origin (Sillitoe, 1988). Gold mineralization (pyrite, chalcopyrite, sphalerite, galena and cinnabar) is disseminated in volcanic rocks with associated $\mathrm{K}$ feldspar alteration (Llaumett, 1980). The mantos are developed in felsic and intermediate volcanic rocks, with thickness between 10 to $20 \mathrm{~m}$ and 1 to $1.5 \mathrm{~km}$ length. A closely related predominantly EW oriented and steeply dipping vein swarm and range from centimetres up to $6 \mathrm{~m}$ wide with similar mineralization as the stratabound mineralization, is also present (Reyes, 1991). 
Oyarzún et al. (1996) indicate that the fluid, which deposited the stratabound gold mineralization, was of moderate salinity and cooled from approximately $365^{\circ}$ to $100^{\circ}$. This observation, combined with restoration of the deposits to their pre-faulting configuration, led the writers to conclude that the $91 \pm 6$ Ma gold mantos (Reyes, 1991) are not derived laterally from the $100 \mathrm{Ma}$ Andacollo porphyry system, but rather from a younger, concealed intrusive located vertically below the gold mantos. To the south of the Andacollo district, Los Mantos de Punitaqui (Fig. 1, Table 1) is a pluton-related vein deposit (Sillitoe, 1991) part of a Mesozoic batholith. Mineralization occurs as veins within a main shear zone and along northwest shear fractures. Gold is contained in a $3.5 \mathrm{~km}$ long quartz vein up to $25 \mathrm{~m}$ wide and known to a maximum depth of $350 \mathrm{~m}$. Hematite, minor magnetite and chalcopyrite are intergrown in quartz veins with subordinate calcite.

In the Coastal Range of the Atacama-Coquimbo Region $\left(26^{\circ}-32^{\circ} \mathrm{S}\right)$, several vein type gold deposits are known: Faro, Costa Rica, Rescatada, Capote, Carrizal Alto, Burladora, Colluntua and Jote (Fig. 1). Henríquez et al. (1991) have classified these gold deposits as mesothermal. Gold deposits are mainly veins hosted in jurassic granitic and granodioritic intrusives or in cretaceous volcanic rocks without alteration halos. They can extend as far as $4 \mathrm{~km}$ in length, but the economic ore bodies tend to be 200 to $400 \mathrm{~m}$ in length reaching depths between 350 and $450 \mathrm{~m}$. Main sulfide minerals are pyrite, chalcopyrite and arsenopyrite in a quartz gangue.

An equivalent setting is also known in the Central Chile coastal range $\left(32^{\circ}-36^{\circ} \mathrm{S}\right)$ (Gröpper, 2011; Camus, 2018) including several gold mining districts: El Bronce de Petorca, Alhué, Chancón and Las Palmas (Fig. 1, Table 1), among others less relevant.

The El Bronce de Petorca district (Fig. 1, Table 1) is composed by an epithermal low sulfidation vein system hosted by Cretaceous volcanic andesitic sequences (Camus et al., 1991). Nearly 90 ore bodies, mostly polymetallic veins, some copper veins, and one copper breccia pipe have been recognized. A $1 \mathrm{~km}$ vertical zonation is described, with a barren upper part followed by sub economic gold plus base metals, then the main gold and base metals zone ending in a sub economic gold plus silver with no base metals lower zone. The most significant and productive ore deposit is the El Bronce vein, emplaced in a $7 \mathrm{~km}$ long, NS-N20E striking fault. Diverse lenticular, structurally controlled ore shoots are detected along the fault, fluctuating from $100-600 \mathrm{~m}$ in length, 200-400 $\mathrm{m}$ in depth, and 1-20 $\mathrm{m}$ in width (Camus et al., 1991). The vein mineralogy is composed of quartz, pyrite, sphalerite, galena, tetrahedrite, barite and calcite. Ore shoots occurs as massive sulfide fillings, stockworks and disseminations.

The Pullalli deposit (Fig. 1, Table 1) consists of fractured and faulted stratabound-like siliceous bodies in a Triassic dome complex intruded by Jurassic granites (Shatwell, 1999). The siliceous bodies are composed of microcrystalline and massive quartz and stockworks of quartz micro veinlets with disseminated pyrite and associated gold. Quartz-sericite and argillic alteration surrounds the siliceous bodies. Maksaev et al. (2007) classified this deposit as mesothermal.

Alhué (Fig. 1, Table 1) is another low-sulfidation epithermal vein district hosted andesitic rocks of Upper Cretaceous age intruded by a granodiorite of the same age (Camus, 1990; Moncada et al., 2015). The ore bodies of this old district, exploited since the XIX siècle, occur as east-west sub vertical veins and consists of a central brecciated portion surrounded by a quartz veinlets stockwork that gradually diminishes in vein density outward. Alteration associated with mineralization is manly silicification, which grades outward into propilitic envelopes. Gold is mainly associated with quartz and pyrite with lesser chalcopyrite and sphalerite. Fluid inclusion studies indicate a vertical zonation with a deeper mesothermal character evolving to an upper epithermal zone (Quintana, 2018)

The Las Palmas is located in the coastal range of south central Chile (Fig.1, Table 1). It is low sulfidation epithermal gold vein district hosted by andesites and volcanic tuffs probably of Middle Jurassic age (Camus and Duhalde, 1982; Gröpper, 2011). Host volcanic rocks have been affected by a propilitic alteration associated with the emplacement of Upper Cretaceous intrusives. Several veins are identified, some of them with a length up to $1.5 \mathrm{~km}$. Veins are mostly filled with quartz, chlorite, pyrite, sphalerite, galena, chalcopyrite and locally magnetite including quartz-serictic alteration grading to silicification at depth.

Cerro Bayo-Fachinal district, in southern Chile (Fig. 1, Table1), is a low to intermediate sulfidation epithermal vein ( 0.5 to $5 \mathrm{~m}$ wide) and hydrothermal breccia (up to $1 \mathrm{~m}$ wide) system (Wheeler,1991; Boetsch, 2014) hosted by Jurassic rhyolite to 
dacitic volcanic ash-flow/tuffs. Veins and breccias consists of quartz with disseminated pyrite, and a complex series of silver sulphosalts with free gold and silver. Minor amounts of sphalerite, lead sulfide and chalcopyrite are also recognized. Illite-smectite are the major alteration minerals in the district (Poblete, 2011). Los Domos is a prospect located nearby Cerro Bayo with similar characteristics (Equus Mining Ltd., 2017).

Skarns type deposits (Maksaev, 2005), are also part of the Mesozoic mineralization but none is known as important regarding its gold content. Several are mentioned as copper deposits (with only one case of a zinc-lead body) with gold as a by-product. Mainly located in the Coastal Range hosted by Lower Cretaceous carbonate rocks. From North to South, Lagarto near Iquique, San Antonio near La Serena, Panulcillo in the Coquimbo Region are IOCG type with some skarn development (Narváez and Aguirre, 2015; Castellón, 2017), Mantos Grandes in the Limarí Province, Cabildo in the Valparaíso Region, La Campana north of Santiago and El Toqui (Zn, $\mathrm{Pb}, \mathrm{Au}$ ) in the Chilean Patagonia are all examples of skarn type deposits with noticeable gold content.

A relevant characteristic for the Mesozoic is the abundance of gold and gold-copper veins many times described as mesothermal (Ruiz et al., 1965; Boric et al., 1990; Vivallo et al., 2008; Camus, 2011; Gröpper, 2011; Arredondo et al., 2017). Most of these deposits are less important regarding their size and unfortunately, information about tonnage-grade is often unknown. Additionally, the Jurassic-Early Cretaceous magmatic arc is characterized by a large variety of ore deposit types including mesothermal and epithermal gold, IOCG, porphyry copper as well as stratabound copper-silver deposits. This gave place due to its geographic location to a definition of a Costal Range Metallogenic Belt (Vivallo et al., 2009). An interesting zonation and lineaments pattern for porphyry copper, IOCG, stratabound $\mathrm{Cu}-\mathrm{Ag}$ and stratabound $\mathrm{Au}$ deposits was also suggested for this belt (Morel, 2009).

\subsection{Cenozoic gold deposits}

Most of the Cenozoic gold deposits seem to be related to eroded volcanic centres and/or sub volcanic intrusives (Davidson and Mpodozis, 1991) and all of them are part of discrete magmatic arcs, parallel to the current coastal line (Cabello, 1986, 1992).
The Paleocene-Eocene magmatic event started some $70 \mathrm{Ma}$ ago, increasing in intensity during the Paleocene due to faster plate convergence (PardoCasas and Molnar, 1987). This magmatism is well exposed in northern Chile as a NS trending belt and these volcanic rocks host the Faride, San Cristóbal, Guanaco and El Peñón gold deposits (Fig. 1).

Faride is a low sulfidation epithermal gold-silver deposit located ca. $80 \mathrm{~km}$ north of the San Cristobal Gold deposit (Fig. 1, Table 1). It is associated with an eroded volcanic centre (Camus and Skewes, 1991; Iriarte, 1993; Garofalo, 2009). Vein type ore bodies extend roughly $2 \mathrm{~km}$, filling discontinuous portions of faults. The veins are oxidized and the hypogene mineralization below $200 \mathrm{~m}$ comprises specularite, chalcopyrite galena, sphalerite and copper-silver sulfosalts, while gangue minerals include quartz, barite, rhodochrosite and siderite with quartz-sericite envelopes around the veins.

San Cristobal mesothermal gold deposit (Fig. 1, Table 2) (Eggert and Kasaneva,1995) is hosted in a 54 Ma complex of felsic porphyries and granitoids intruded by a series of quartz porphyries and hydrothermal breccias (Maksaev, 1990). The deposit comprises low grade disseminated mineralization and gold bearing NS quartz veins up to $2 \mathrm{~km}$ long and $1 \mathrm{~m}$ average thickness associated with potassic, propilitic and phyllic alteration. The bulk gold resource includes four ore shoots irregularly distributed forming a NW elongated body $1 \mathrm{~km}$ long, $300 \mathrm{~m}$ across and $200 \mathrm{~m}$ deep, which formed where the vein system crosses a sub volcanic complex.

Guanaco (Fig. 1, Table 1) is a high-sulfidation gold-copper district probably situated above a porphyry copper system and genetically related to a caldera with dacitic flows and domes (Puig et al., 1988; Cuitiño et al., 1988; Jovic et al., 2015). The gold mineralization is contained in ledges of vuggy silica up to $50 \mathrm{~m}$ wide with sulphides which includes enargite, auriferous pyrite, arsenopyrite and sparse chalcopyrite (Vidal et al., 2019). Ore bearing ledges are surrounded by advanced argillic alteration comprising alunite, pyrophyllite, kaolinite and dickite.

Discovered in 1994, El Peñón deposit is the largest gold-silver deposit associated with the Paleocene volcanic event. The deposit is a low sulfidation epithermal vein system genetically related with a Paleocene-age rhyolite flow dome complex (Arancibia et al., 2006). The fault controlled mineralization has been K-Ar dated at 52 to $53 \mathrm{Ma}$ (Warren et al., 2008), 
broadly coincident with the ${ }^{40} \mathrm{Ar} /{ }^{39} \mathrm{Ar}$ age of 53-51 Ma for vein adularia (Arancibia et al., 2006). Gold -silver mineralization is associated with a variety of quartz vein textures and grain sizes. Chalcedonic to coarsegrained quartz occurs in banded, sacharoidal, comb and bladed carbonate replacement vein textures. Hydrothermal breccias are common and constituted important structural preparation for vein formation. The oxidised zone of the deposit extends 250 to $280 \mathrm{~m}$ below the surface. Mineralogy consists largely of silver halides, native silver and electrum with a gangue of quartz, adularia, calcite, rhodochrosite, dolomite and other carbonate minerals (Bissig et al., 2007). Trace amounts of sphalerite, galena and chalcopyrite are present below the oxidised zone. Some $10 \mathrm{~km}$ north of El Peñón, a high sulfidation gold porphyry system named El Anillo has been described (Marquardt et al., 1994), associated to a younger episode of intrusive activity (48-42 Ma).

The Amancaya gold deposit is located south of El Peñón mine. It is a low sulfidation, epithermal deposit, hosted in a steeply dipping, structurally controlled, quartz vein (Altman et al., 2017).

The Late Eocene-Early Oligocene period was characterised by a clear magmatic intensity decrease (McKee and Noble, 1990), immediately following initiation of the Upper Eocene compressive stage. During this period, several of the most important Andean porphyry copper deposits or districts were formed (e.g., Collahuasi, Chuquicamata, Centinela, Escondida, El Salvador, Fig. 1.), associated with transcurrent north-south faults related to crustal weakness (Maksaev and Zentilli, 1988).

At least three high sulfidation gold deposits, apparently related to porphyry copper systems, of this age have been described:

El Hueso and Agua de la Falda-Jerónimo (Fig. 1, Table 1), both located close to the Potrerillos porphyry copper system (Colley et al., 1989; Marsh et al., 1997); and the Cantaritos prospect located in the vicinity of La Fortuna porphyry copper (Perelló et al., 1996). At El Hueso Jurassic-Cretaceous limestones and silstones intruded by dacitic-andesite stocks and overlain by siliceous tuffs and breccias host the epithermal ore deposit. Much of the ore occurs as tabular and steeply dipping silicified zones in limestone and volcaniclastics. Agua de La FaldaJerónimo is located $2 \mathrm{~km}$ East of El Hueso. Here stratabound gold and sulfide mineralization was mainly deposited in silicified calcareous sandstones
(Thompson et al., 2004). Pyrite is by far the main sulfide mineral, but marcasite, arsenopyrite, sphalerite, galena, bournonite and pyrargirite are also found. In the Cantaritos prospect inland of Vallenar city, alunite-vuggy silica alteration occurs $1 \mathrm{~km}$ SE of the El Morro-La Fortuna copper-gold porphyry prospect (Fig. 1, Table 1). Advanced argillic alteration at Cantaritos has yielded a $32 \mathrm{Ma}$ age, similar to that of the porphyry deposit (Salazar and Coloma, 2016). Two other small low sulphidation epithermal occurrences associated with volcanic rocks of the same age have also been reported: they are the Choja and Tinaja diatreme related prospects (not included in the location map), inland of the Iquique and Copiapo cities (Sillitoe, 1992).

Volcanic rocks of Upper Oligocene-Late Miocene age host some of the larger gold deposits. Volcanism of this period, was formed during a time of faster and less oblique plate convergence (Pilger, 1984). A shallowing subduction zone generated a greater width of the related volcanic arc, as well as of the associated mineralization (Sillitoe, 1992). Two types of gold deposits are in this magmatic belt: high sulfidation epithermal deposits in the so-called Maricunga and El Indio belts and porphyry gold deposits also occurring in the Maricunga region (Vila and Sillitoe, 1991). These gold deposits formed from 10 to $6.2 \mathrm{Ma}$ (Bissig et al., 2001; Sillitoe, 2008), after andesitic volcanism in the region had ceased (Kay et al., 1999) and the magmatic activity had moved to the east (Bissig et al., 2003). Volcanic rocks in both districts overly Upper Paleozoic granitic and felsic volcanic basement with clear evidence of crustal assimilation (Davidson and Mpodozis, 1991). Considering the tonnage and grade information available (Table 1) can be reported a gold content of 3,189 $\mathrm{t}$ for the Maricunga belt (14 deposits) and 1,310 t for the El Indio belt (4 deposits).

In the Maricunga belt, La Coipa (Fig. 1, Table 1) (Oviedo et al., 1991; Gamonal et al., 2015) is the most important gold-silver high sulfidation epithermal deposit formed between 19 and $14 \mathrm{Ma}$, including tabular and irregular bodies hosted by Triassic sedimentary rocks and Eocene-Oligocene stratovolcanic and dacitic-block rhyolite dome complexes (Kay et al., 1999; Belanger, 2003; Callan, 2019). Another high sulfidation example is the Chimberos-Esperanza silver-gold deposits, also associated with dacitic dome complexes (Vila, 1991a; Lagos, 2010). Here exists a highly silicified, structurally localised hydrothermal 
breccia containing high silver grades and minor gold values. A case related to a somehow recent discovery is the Volcán deposit (Lewis et al., 2011), where mineralization is related to the emplacement of Miocene age calc-alkaline volcanic and sub-volcanic units over basement rocks of Paleozoic to Cenozoic age. The structural setting of the Volcán deposit (Fig. 1) is related to, and associated with, the Copiapó stratovolcano and may also be related to regional northerly-trending high angle reverse faulting. The gold deposit includes an arrangement of gold bearing quartz-pyrite veinlets with outer disseminated pyrite developed in argillic-silica altered tuffaceous and porphyritic dacitic volcanic rocks, as well as in dacitic dome complex. The most recent discovery of this prolific belt is the Salares Norte deposit, a high sulphidation epithermal system with pyritic sulfide mineralization, hosted by a breccia complex close to the contact of two volcanic domes of andesitic and dacitic composition (Brewer et al., 2017). The ore is mainly oxidized gold mineralization.

La Pepa (Fig. 1, Table 1) is a high sulfidation vein and breccia hosted epithermal system with an associated low-grade porphyry style deposit, named Cavancha (Muntean and Einaudi, 2001). Predominant host rocks are dacites, dacitic tuffs and brecciated rhyolites. Alteration mainly corresponds to advanced argillic with dominant quartz and alunite replacements. Kaolin and halloysite crosscut both quartz and alunite. Gold mineralization is largely associated with pyrite, limonite, and minor enargite. Gangue minerals are quartz, alunite, barite and clays.

A distinctive feature of the Maricunga belt is the presence of several gold rich porphyry systems emplaced beneath andesitic stratovolcanoes and related with dioritic to quartz-dioritic porphyritic intrusives and vast hydrothermal alteration zones (Vila and Sillitoe, 1991; Muntean and Einaudi, 2001; Gamonal and Bissig, 2019; Naranjo et al., 2019). They mainly include gold-(copper) mineralization in well-developed quartz stockworks. Iron oxides, both early magnetite and late hematite, constitute up to 10 percent of mineralized rocks. The Marte and Lobo deposits are classified as porphyry gold deposits but Refugio and Cerro Casale are closer to gold rich porphyry coppers (Vila and Sillitoe, 1991). A number of those porphyry systems present an overprint of advanced argillic alteration including quartz-alunite, pyrite, bornite, native sulphur and enargite (Vila, 1991b). Other new example is the
Caspiche gold-copper deposit (Fig. 1, Table 1) related to a dioritic stock beneath post mineral cover where most of the gold and copper (pyrite-chalcopyrite) was introduced during the potassic alteration stage partially overlapped by a molybdenum-rich halo. An upper advanced argillic alteration is also present. (Sillitoe et al., 2013). Cerro Maricunga, also known as Fenix (Fig. 1, Table 1), is another addition to this belt with gold mineralization in dacitic and andesitic intrusive domes restricted to a NW-SE strip with a porphyry and breccia complex limited by faults including pyritemagnetite mineralized zones usually associated to black banded quartz veinlets (Easdon, 2010).

The El Indio belt (Fig. 1), is a 200-km long near continuous belt of hydrothermal alteration centers (Maksaev et al., 1984; Siddeley and Araneda, 1990; Bissig et al., 2002) preserved within a north-south graben system, controlled by high angle faults (Nasi et al., 1990). The extended hydrothermally altered zones appear related to porphyritic stocks. Gold mineralization occurs in various styles: Vein systems (El Indio and Sancarrón), fault and hydrothermal breccias (Tambo) and stratabound deposits (Pascua). The El Indio (Fig. 1, Table 1) high -sulfidation precious metals deposits are characterised by sulfide -rich mineralization in two principal type of veins: those dominated by copper (mainly enargite), and those dominated by gold. The Tambo deposits are sulfate-rich and have native copper and free gold mineralization that is mainly contained in tectonic-hydrothermal breccias associated with alunite and barite (Jannas et al., 1999). Alturas is a recently discovery in this belt, announced in 2015. Correspond to a pervasively oxidized disseminated high sulfidation epithermal gold deposit related to subvolcanic dacitic flows and domes as well as a diatreme complex including a shallow steam heated zone in a typical advanced argillic alteration. Mineralization appears associated to a silicification event. (Astorga et al., 2017).

During the Upper Miocene time, in northern Chile $\left(18^{\circ}-28^{\circ} \mathrm{S}\right)$ an important Miocene to Recent volcanic zone (Gardeweg and Ramírez, 1984) known as the Central Volcanic Zone developed. This zone was characterised by stratovolcanoes, calderas, and ignimbritic sequences with associated advanced argillic and solfataric hydrothermal alteration zones. These alteration zones could present important contents of native sulphur, exposed if the volcanic edifices have been eroded (Davidson and Mpodozis, 1991). Research on sulphur isotopes of the Copiapó volcano 
(Zentilli et al., 1988, 1991) suggests a correlation between solfataric alteration zones and precious metal epithermal systems. At least two gold occurrences are known to be associated with this Miocene magmatic arc. The main one is the Choquelimpie high sulfidation epithermal deposit (Fig. 1). Gold-silver mineralization occurs in veins and hydrothermal breccias hosted in an eroded dacitic-andesitic stratovolcano intruded by similar composition domes (Cabello, 1986; Gröpper et al., 1991). The second case is the Pimentón mine located in the Andes cordillera of central Chile. Here epithermal high sulfidation gold veins are probably related to a porphyry copper system. Individual veins typically form ore shoots up to $450 \mathrm{~m}$ long, up to $50 \mathrm{~cm}$ wide, containing massive pyrite and chalcopyrite with a gangue of barite (Pardo, 2006; McGregor and Brady, 2016).

\section{Placer gold deposits.}

The first historic period of gold production in Chile was from 1541 to the end of the sixteenth century, when a series of gold rich alluvial deposits, mainly located in the central-south portion of the country, produced an estimated 1 or 2 metric tons of gold annually (Cuadra and Dunkerley ,1991). At that time, some of the main producing fields were Andacollo, Marga-Marga, Casablanca, Catapilco, Nirivilo, Lonquimay, Carahue and Madre de Dios. In the nineteenth century, alluvial gold was discovered in Tierra del Fuego (Río del Oro) in the far south of Chile with production for a period of about 40 years including some dredge operations. Chilean secondary gold deposits can be classified as alluvial, eluvial and beach placers (Ruiz and Peebles, 1988; Portigliati et al., 1988; Greiner, 1991). Currently, placer gold mining in Chile is at a very low scale having almost no impact in the country production statistics.

\section{Gold as a by-product of copper deposits.}

From the 2019 reported mining production (Sernageomin, 2020), it is estimated that $64 \%$ of Chile's annual gold production can be attributed to by-product production from copper (largely) and lead-zinc deposits. The following copper deposits are known as important regarding their gold content and production:

The Iron Oxide-Copper Gold (IOCG) belt contains deposits as Mantoverde, La Candelaria, Atacama
Kozan and Punta del Cobre near the coastal range of the Atacama Region (Marschik et al.,1997; Richards et al., 2016). These deposits seem to be confined to a belt of early Cretaceous magnetite-apatite deposits of probable magmatic-hydrothermal origin and may be considered as copper-rich end member of these iron dominated deposits (Sillitoe, 1994, 2003; Vivallo, 2009). Hosted by Lower Cretaceous andesites and sedimentary sequences they appear to be associated to mid-Cretaceous dioritic to granodioritic plutons and their late stage differentiates (Marschik et al., 2000). Orebodies are stratabound concentrations of magnetite, pyrite, chalcopyrite, and gold but also include stockworks, breccias, disseminations, veins and massive replacements by the same minerals. Gold content in these deposits varies between 0.05 to $0.6 \mathrm{~g} / \mathrm{t} \mathrm{Au}$, with an estimated average of $0.2 \mathrm{~g} / \mathrm{t}$ based on the 14 deposits here reported (Table 2). Regarding it total gold content the most important is Candelaria ( $65 \mathrm{t}$ ), followed by Mantoverde ( $52 \mathrm{t}$ ) and Cerro Negro (37 t).

At least some 34 porphyry copper deposits and/ or districts of different ages are known to contain gold (Table 3). In spite of their mostly low gold content, due to their sometimes huge reserves, porphyry coppers represent a major source of gold in the Chilean Andes. The gold content of the Chilean porphyries has been only partially documented yet (Perelló and Cabello, 1989) but seems to be enough to realize their importance regarding the content of this precious metal. Previous studies mentioned as deposits with important gold content the cases of Andacollo (Llaumett et al., 1975), Quebrada Blanca (Hunt et al., 1983), El Salvador (Roschmann, 1979) and Potrerillos (Marsh et al., 1997). According to the compilation presented in table 3 , publically reported average gold content varies between 0.01 to $0.7 \mathrm{~g} / \mathrm{t}$, resulting in $0.15 \mathrm{~g} / \mathrm{t}$ average content for the 34 cases included. As in the Mesozoic case there are a few mentions of skarn type mineralization related to porphyry copper: they occur in the Centinela District at the Mirador deposit (Apablaza, 2015) as well as in Potrerillos and Escalones, but is not clear yet its influence in gold content for those deposits. Reviewing their gold total content, the first place is for El Teniente (513 t) (Camus, 2003) followed by El Morro-Fortuna District (490 t) (Perelló et al., 1996, Lambert et al., 2012) and Pampa Escondida (446 t) (BHP, 2018), all this cases are obviously influenced by their huge tonnage. The Esperanza and Escondida 
porphyry copper deposits are mentioned as the current more important gold producer for this ore deposit type. Several other porphyry copper deposit including some recently discovered could have a gold content not known or publically reported yet: Radomiro Tomic, Ministro Hales, Escondida Norte-Zaldívar, Escondida Este, Vizcachitas, San Enrique-Monolito, La Huifa among others. Considering their important mineralized volumes, they could provide significant additional gold resources.

\section{Gold mineralization: geological ages, ore deposit types, and mineral belts}

The grade and tonnage for the different ore deposits considered in this work are presented in tables 1, 2 and 3. A note is made regarding the gold resources reported in this article: all is public information estimated to be valid at the time when obtained. Therefore, past mined gold statistics was not available for current or closed mines identified in this paper. Using this information was calculated the amount of gold concentrated during the different geological epochs and it relationship to the diverse ore deposit types both of precious and base metals (Figs. 2-7).

If we consider those (Table 1) defined as gold deposits group (31 cases), mainly epithermal precious metals deposits and porphyry gold, the gold concentrations are (Fig. 2): Mesozoic, $238 \mathrm{t}$ (5\%), Paleocene, 339 t (6\%), Eocene-Oligocene $126 \mathrm{t}(2 \%)$ and Miocene, 4,524 t (87\%). Within the same group but according to the gold content in the different deposit types, the following distribution is obtained (Fig. 3): mesothermal $113 \mathrm{t}$ (2\%), epithermal LS $424 \mathrm{t}(8 \%)$, epithermal HS 2,027 t (39\%) and porphyry Au 2,663 t (51\%).

In the porphyry copper group (35 cases) the distribution of gold content is (Fig. 4): Mesozoic, 188 t (3\%), Paleocene, 342 t (6\%), Eocene-Oligocene, $3,842 \mathrm{t}(63 \%)$ and Mio-Pliocene, 1,675t (28\%).

And if we take all 82 deposits types (this means those defined as gold deposits plus porphyry coppers and IOCG) the gold content distribution according the geological age is (Fig. 5): Mesozoic, $778 \mathrm{t}(7 \%)$, Paleocene, 681t (6\%), Eocene-Oligocene, 3,968 t (34\%) and Mio-Pliocene, 6,234 t (53\%). But based on the deposit type, the following gold distribution is obtained (Fig. 6): gold deposits 5,227 t or $168 \mathrm{Moz}$ (45\%), IOCG 352 t or $11 \mathrm{Moz}(3 \%)$ and porphyry copper 6,082 t or $195 \mathrm{Moz}(52 \%)$.

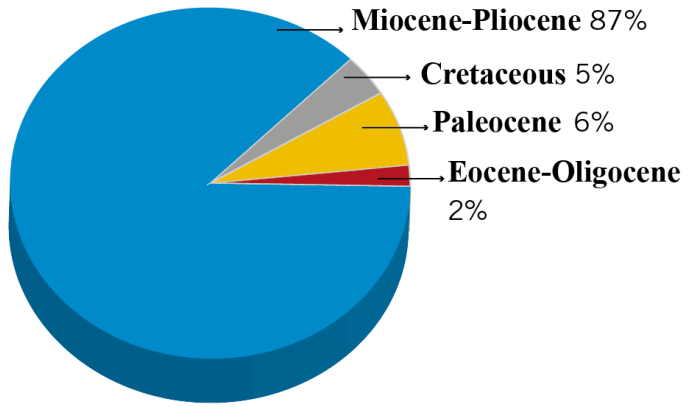

Miocene-Pliocene

$4,524 \mathrm{t}$

Paleocene

$339 \mathrm{t}$

Cretaceous

$238 \mathrm{t}$

Eocene-Oligocene

$126 \mathrm{t}$

Fig. 2. Gold content (\%) in different geological epochs and periods based on 31 main gold deposits (Table 1). Cretaceous 238 t (6 deposits), Paleocene 339 t (4 deposits), Eocene-Oligocene $126 \mathrm{t}$ (2 deposits), Miocene 4,524 t (19 deposits).
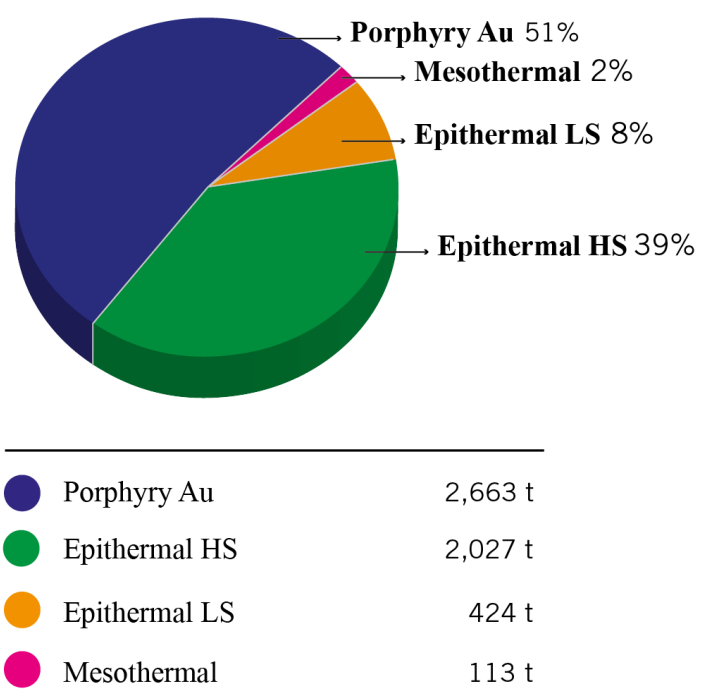

Fig. 3. Gold content (\%) in different deposit types based on 31 main gold deposits (Table 1). Mesothermal $113 \mathrm{t}$ (2 deposits), Epithermal LS 424 t (7 deposits), Epithermal HS 2,027t (15 deposits), Porphyry Au 2,663 t (7 deposits). 


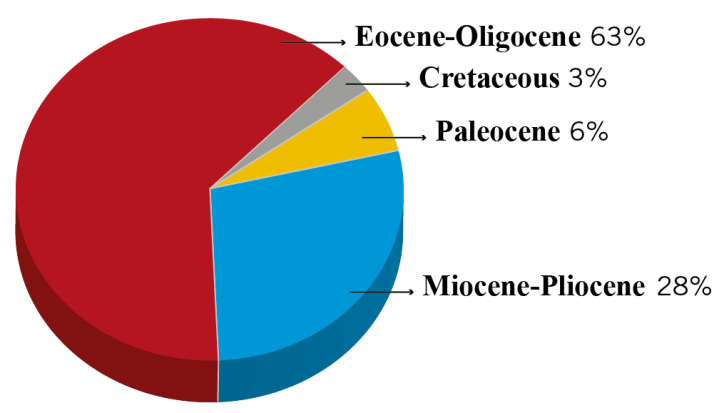

\begin{tabular}{lr}
\hline Eocene-Oligocene & $3,842 \mathrm{t}$ \\
Miocene-Pliocene & $1,710 \mathrm{t}$ \\
Paleocene & $342 \mathrm{t}$ \\
Cretaceous & $188 \mathrm{t}$
\end{tabular}

Fig. 4. Gold content (\%) in different geological epochs and periods based on 35 porphyry Cu-Mo-Au deposits (Table 3). Cretaceous $188 \mathrm{t}$ (4 deposits), Paleocene $342 \mathrm{t}$ (4 deposits), Eocene-Oligocene 3,842 t (19 deposits), Miocene-Pliocene 1,710 t (8 deposits).

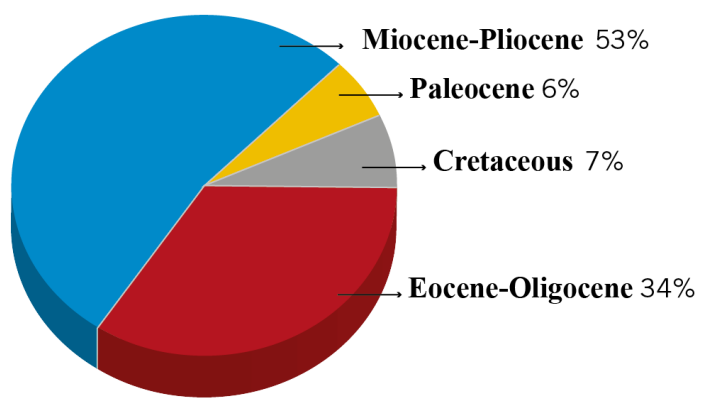

\begin{tabular}{lr}
\hline Miocene-Pliocene & $6,234 t$ \\
Eocene-Oligocene & $3,968 t$ \\
Cretaceous & $778 t$ \\
Paleocene & $681 t$
\end{tabular}

Fig. 5. Gold content (\%) in different geological epochs and periods based on 82 deposits (Tables 1,2,3). Cretaceous 778 t (26 deposits), Paleocene 681 t ( 8 deposits), EoceneOligocene 3,968 t (21 deposits), Miocene-Pliocene 6,234 t (27 deposits).

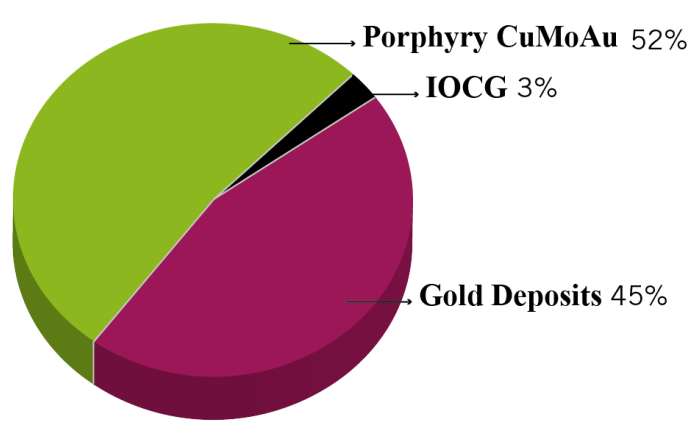

Porphyry CuMoAu

$6,082 \mathrm{t}$

Gold Deposits

$5,227 t$

IOCG

$352 t$

Fig. 6. Gold content (\%) in different deposit types based on 82 deposits (Tables 1, 2, 3). Porphyry Cu-Mo-Au 6,082 t (35 deposits), Gold deposits 5,227 t (31 deposits), IOCG $352 \mathrm{t}$ (16 deposits).
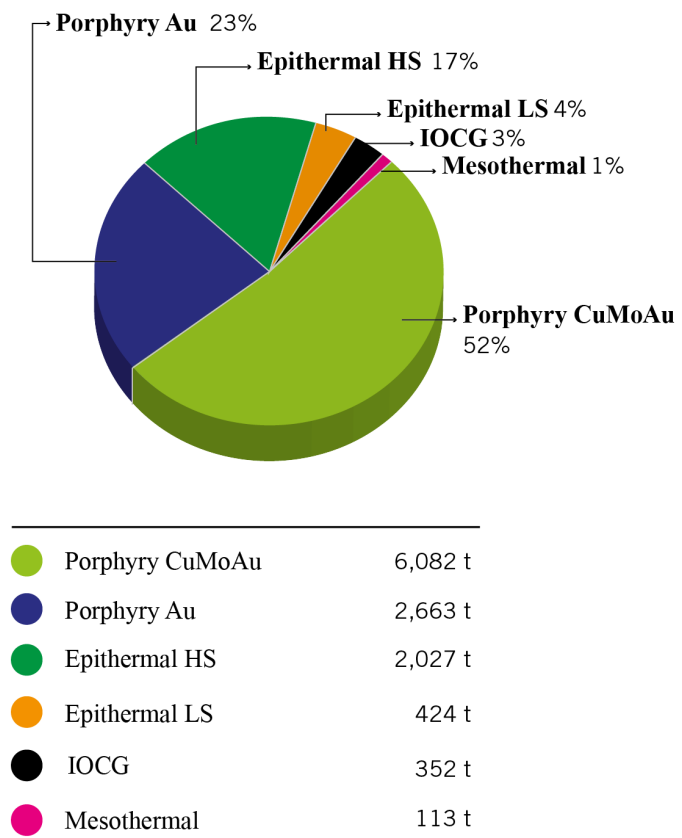

Fig.7. Gold content (\%) in different deposits type based on 31 main gold deposits (Table 1), 16 IOCG deposits (Table 2) and 35 porphyry $\mathrm{Cu}-\mathrm{Mo}-\mathrm{Au}$ deposits (Table 3 ). Mesothermal 113 t (2 deposits), Epithermal LS 424 t (7 deposits), Epithermal HS 2,027 t (15 deposits), Porphyry Au 2,663 t (7 deposits), IOCG 352 t (16 deposits), Porphyry Cu-Mo-Au 6,082 t (35 deposits). 
And when compared (Fig. 7) all the ore deposit types in the 3 groups, the gold concentration is: Mesothermal 1\% (113 t), epithermal LS 4\% (424t), epithermal HS 17\% (2,027 t), Porphyry Au 23\% (2,663 t), IOCG, 3\% (352 t) and Porphyry Cu 52\% $(6,082 \mathrm{t})$. If we bring together Porphyry Au with Porphyry $\mathrm{Cu}$, they represent $75 \%(8,745 \mathrm{t})$ of the gold concentration reflecting their metallogenic and economic relevance.

And all together represent an estimated number of $11,662 \mathrm{t}$ equivalent to $375 \mathrm{Moz}$ similar to a recent publication (Beard and Jowitt, 2019). And should be added that several potential gold bearing base metals deposits (both porphyry copper and IOCG) do not include their gold content in public format, therefore the number provided could be estimated conservative.

The Maricunga and El Indio are clearly the main gold belts in Chile. The Maricunga belt (Sillitoe, 2008) cover a length of approximately $200 \mathrm{~km}$ (between $26^{\circ}$ and $28^{\circ} \mathrm{S}$ ) with porphyry and high sulfidation epithermal gold deposits occurring in two partly overlapping NS remarkable belts where mineralization considered to be emplaced during two different episodes at 25-20 Ma and 15-13 Ma (Sillitoe et al., 1991). In Maricunga are reported some 14 deposits ( 7 high sulfidation epithermal gold deposits and 7 porphyry gold), which in total represent 3,189 t of gold (approx. $103 \mathrm{Moz}$ ). Further south, the El Indio belt (Bissig et al., 2015; Jara et al., 2019) is about $100 \mathrm{~km}$ long (between $29^{\circ}$ and $30^{\circ} \mathrm{S}$ ). Gold deposits were formed between 9.5 and 5 Ma (Bissig et al., 2001). No porphyry gold is yet identified here. El Indio belt includes 4 high sulfidation gold deposits as Pascua-Lama, the now historic El Indio, Tambo and the recent discovery of Alturas, accounting altogether for 1,310 t of gold or $42 \mathrm{Moz}$.

\section{Exploration, development and production}

In a review of the last five decades, the rate of growth of Chilean gold production is indeed impressive. In the period 1969-1998, gold production increased 27 times from 1,827 to 49,700 kg., after that, the level of production has been kept at a good level always above $35,000 \mathrm{~kg}$ per year. Several facts explain that increase of production, the most important being the success of exploration sustained over the same period (Cabello, 1999; Sillitoe, 1995, 2000, 2010).
This resulted in the discovery and development of several world-class deposits which account for a big part of the production increase.

Between 1969 and 1998, at least 18 precious metals discoveries were made. Of these, the most important and best known are El Indio mining district, La Coipa, Pascua, Refugio and Cerro Casale. These 18 discoveries collectively represented an in-ground resource of more than $1,763 \mathrm{t}$ of gold.

In 1979, El Indio was the first of the new gold discoveries to become a mine. Of the 18 discoveries, 13 have been developed into mines. Of these, three were subsequently closed down (Choquelimpie, El Hueso and El Indio).

During the new siècle, the positive exploration trend has continued with several important discoveries like Volcán, Caspiche, Alturas and Salares Norte.

And parallel to these gold deposit discoveries happened important gold bearing copper deposit discoveries including both porphyry coppers and IOCG type deposits. All this is clearly reflected in the mining development and production statistics (Cochilco, 2010; Sernageomin, 2020).

Different technical reports mention future development for deposits like Salares Norte, Nueva Esperanza-Arqueros, Cerro Maricunga, Cerro Casale and Caspiche. Therefore, an increment of the country gold production is expected.

\section{Concluding Remarks}

The hydrothermal gold deposits in the Chilean Andes are closely associated with subduction related magmatic arcs. Due to its relationship with episodic magmatism migrating eastward, there is a general tendency for hydrothermal gold deposits to be in discrete NS trending belts presenting a progressive west to east decrease in mineralization age.

Excluding Andacollo, El Bronce de Petorca, Pullalli and Alhué, Mesozoic deposits are quite abundant but less relevant regarding their size and gold content. They are mainly vein deposits located in the coastal range and many of the mesothermal gold deposits are hosted in plutonic rocks. Erosion must be a factor to explain importance of intrusive rocks as host rocks with a genetically relationship with gold mineralization.

The Miocene high sulfidation epithermal and gold porphyry type deposits are the most important (La Coipa, Refugio, Cerro Casale, Pascua, El Indio) 
suggesting a correlation with a faster and less oblique plate convergence. The same characteristic seems to have occurred in the Upper to Middle Eocene (El Guanaco, El Hueso, and Agua de La Falda-Jeronimo).

In general, the close correlation of Cenozoic gold deposits with volcanic centers and sub volcanic intrusives seems to be clear (Cabello, 1986, 1992; Davidson and Mpodozis, 1991). In addition, the relationship of the Cenozoic deposits with volcanic landform is quite evident in several cases (Choquelimpie, Volcán, Marte and Lobo). An association with dome complexes is reported in Guanaco, La Coipa, and Esperanza as well as in Pullalli and Choquelimpie. In El Guanaco, a caldera type structure is considered important (Puig et al., 1988). El Indio is said to be associated with a caldera structure (Jannas et al., 1990) or alternatively to an eroded stratovolcano (Sillitoe, 1991).

Erosion has an important influence in relation to the absence or presence of gold deposits (Camus, 1990; Sillitoe, 1991). As a rule, it can be pointed out that the level of erosion decreases from west to east in the Andes, explaining the scarcity or absence in the pre and post Miocene periods. In the first case, deep erosion has removed the volcanic edifices, and in the second case erosion has not been sufficient to unroof the potentially mineralized centers.

Gold bearing copper deposits constitute an important part of Chile's total gold production. Both IOCG type but especially porphyry copper are and will remain as significant sources to complement the future output of the gold deposits.

In summary, the 82 deposits with tonnage and grade studied represent gold content as follow: gold deposits 5,227 t or $168 \mathrm{Moz}$, IOCG $352 \mathrm{t}$ or $11 \mathrm{Moz}$ and porphyry copper $6,082 \mathrm{t}$ or $195 \mathrm{Moz}$. And all together signify an estimated number of 11,662 t equivalent to $375 \mathrm{Moz}$. Moreover, should be added that a number of potential gold bearing base metals deposits (both porphyry copper and IOCG) do not include their gold content in public format, hence, the number provided could be estimated conservative. This figures support future maintenance of Chile's current gold production level as well as eventual important increases if undeveloped project come into production.

\section{Acknowledgements}

The author would like to thank the support given to this article by the Mineralium Consulting Group. The cooperation of X. Prieto during the stage of data collection is greatly appreciated. The early draft of the manuscript benefited from reviews by Ch. Ford, F. Henriquez and W. Vivallo carefully revised the document and made numerous suggestions that assisted to greatly improve previous versions of the manuscript.

\section{References}

Altman, K.A.; Cox, J.J.; Moore, C.M.; Weir, I. 2017. Technical Report on the Guanaco and Amancaya Gold Project, Antofagasta Region (II), Chile. NI 43-101 Report, Austral Gold Ltd.-RPA: 377 p.

Andina Mineral Inc. 2012. Press Release, Acquisition of the Volcán Gold Deposit: 2 p.

AMSA, 2017. Ore Reserves and Mineral Resources Estimates. In Antofagasta PLC Annual Report: $216 \mathrm{p}$.

Apablaza, P. 2015. Porphyry and skarn copper mineralization at Mirador, Centinela District, northern Chile. In Congreso Geológico Chileno, No. 14: p 356. La Serena.

Arancibia, G.; Matthews, S.; Cornejo, P.; Pérez de Arce, C.; Zuluaga, J.; Kasaneva, S. 2006. ${ }^{40} \mathrm{Ar} /{ }^{39} \mathrm{Ar}$ and K-Ar geochronology of magmatic and hydrothermal events in a classic low-sulphidation epithermal bonanza deposit: El Peñón, northern Chile. Mineralium Deposita 41 (5): 505-516.

Armitage, A.; Davis, C. 2012. Resource Estimate on the Escalones Porphyry Copper Project, South American Silver Corp., GeoVector Management Inc.: 50 p.

Arredondo, C.; Moscoso, R.; Prieto, X.; Ortega, R.; Carrasco, R.; Vivallo, W.; Mateo, L.; Pantoja, G.; Ulloa, M.; Ercilla, O.; Ridelle, E. 2017. Depósitos Minerales de la Región de Coquimbo. Servicio Nacional de Geología y Minería, Carta Geológica de Chile, Serie de Recursos Minerales y Energéticos 35: 134 p., 2 mapas escala 1:500.000, $1 \mathrm{CD}$ con anexos. Santiago.

Arribas, A.; Illanes, J.L.; Peralta, C.; Fuentes, M.; Kowalczyk, P.; Taufen, P. 2005. Geochemical study of the steam-heated cap above the Puren deposit, La Coipa mine, Chile. Geological Society of Nevada Conference, Reno, Graphic Presentation: 20 slides.

Astorga, D.; Griffiths, S.; Crosato, S.; Jorquera, C.; Plasencia, C. 2017. Alturas: A unique discovery within a mature district trough integrating sound geological practices, multidisciplinary expertise and leading technology. In Proceedings of Exploration 17: Sixth Decennial International Conference on Mineral Exploration (Tschirhart, V.; Thomas, M.D.; editors): 587-600.

Atna Resources Ltda. 2002. Cerro Negro Copper Project, Region III; Chile, Unpublished Report, Minera Atna Chile Limitada: 17 p. 
Barrick. 2016. Alturas, Geology and Discovery, Toronto Geological Discussion Group, Graphic Presentation: 22 slides.

Beard, E.; Jowitt, S. 2019. Gold Resource Distribution in South America. SEG South American Conference: Sierra to Craton, Abstracts: 1 p.

Belanger, M. 2003. La Coipa Mine, Chile. Technical Report Prepared for Kinross Gold Corporation: 231 p. BHP. 2018. BHP Annual Report: 300 p.

Bissig, T.; Lee, J.K.W.; Clark, A.H.; Heather, K.B. 2001. The Cenozoic history of volcanism and hydrothermal alteration in the central Andean flat-slab region: New ${ }^{40} \mathrm{Ar} /{ }^{39} \mathrm{Ar}$ constraints from the El Indio-Pascua $\mathrm{Au}$ (Ag, $\mathrm{Cu}$ ) belt, $29^{\circ} 20^{\prime}-30^{\circ} 30^{\prime} \mathrm{S}$. International Geology Review 43: 312-340.

Bissig, T.; Clark, A.H.; Lee, J.K.W.; Hodgson, C.J. 2002. Miocene Landscape Evolution and Geomorphologic Control on Epithermal Processes in the El Indio-Pascua Au-Ag-Cu Belt, Chile and Argentina. Economic Geology 97: 971-996.

Bissig, T.; Clark, A.H.; Lee, J.K.W.; von Quadt, A. 2003. Petrogenetic and metallogenetic responses to Miocene slab flattening: new constraints from the El IndioPascua Au-Ag-Cu Belt, Chile/Argentina. Mineralium Deposita 38: 844-862.

Bissig, T.; Donoso, D.; Guerra, N.; Dipple, G. 2007. Vein carbonates in the low sulfidation epithermal Au-Ag District of El Peñón, II Región, Chile: environment of formation and exploration implications. Revista Geológica de Chile 34 (2): 291-304. doi: 10.5027/ andgeoV34n2-a07.

Bissig, T.; Clark, A.H.; Rainbow, A.; Montgomery, A. 2015. Physiographic and tectonic settings of highsulfidation epithermal gold-silver deposits in the Andes and their controls on mineralizing processes. Ore Geology Reviews 65: 327-364.

Bloch, W.; Schurr, B.; Kummerow, J.; Salazar, P.; Shapiro, S.A. 2018. From slab coupling to slab pull: Stress segmentation in the subducting Nazca plate. Geophysical Research Letters 45: 5407-5416.

Boetsch, M. 2014. Control Estructural de la Mineralización Argento-Aurífera y Criterios de Exploración en el Distrito Cerro Bayo, Región de Aysén, Chile. Memoria de Titulo (Unpublished), Departamento de Geología, Universidad de Chile: $163 \mathrm{p}$.

Boric, R.; Díaz, F.; Maksaev, V. 1990, Geología y yacimientos metalíferos de la región de Antofagasta. Servicio Nacional de Geología y Minería-Chile, Boletín 40: 246 p.

Brewer, N.; Azevedo, F.; Huete, D.; Guevara, T.; Rojas, F.; Rodríguez, J.; Lagos, C.; Cerda, C.; Moreno, C.;
Baumgartner, R.; Trueman, A.; Foley, A. 2017. The Discovery and Geology of the Salares Norte Epithermal Gold-Silver Deposit, Northern Chile. AME Roundup 2017, Power Point presentation: 21 slides. Vancouver. Brimage, D.; Rennie, D.W.; Nilsson, J.; Winkers, A.; Davies, M. 2011. Technical Report on the Santo Domingo Project: 295 p. Ausenco.

Cabello, J. 1986. Precious metals and cenozoic volcanism in the Chilean Andes. In Exploration for Ore Deposits of the North American Cordillera (Nichols, C.E.; editor), Journal of Geochemical Exploration 25: 1-19.

Cabello, J. 1992. Metales Preciosos y Volcanismo Cenozoico en los Andes Chilenos: Revisión Actualizada. In Seminario Taller Procesos Formadores de Depósitos Epitermales de Metales Preciosos, SernageominBID: 83-90.

Cabello, J. 1999. Exploration Discoveries in Chile: The Last Three Decades. Proceedings PACRIM 99 Conference: 207-210. Bali.

Cabello, J. 2002. Geología, Exploración y Recursos de los Yacimientos de Oro en Chile, EXPOMIN, Power Point Presentation: 44 slides. Santiago.

Cabello, J. 2013. Auditoría Geológica Mina La Tigresa, Distrito Ojancos Viejo, III Región, Chile. Cía. Minera Carmen Bajo. Informe Inédito: 287 p.

Callan, N. 2019. An Updated Geological Model for High-Sulphidation Epithermal Ag-Au Mineralization, Huantajaya-Chimberos Sector, Nueva Esperanza Project, Maricunga District, N. Chile. SEG South American Conference, Sierra to Craton: Abstracts: 3 p.

Camus, F. 1990. The geology of hydrothermal gold deposits in Chile. In Epithermal Gold Mineralization of the Circum-Pacific. Geology, Geochemistry, Origin and Exploration (Hedenquist, J.W.; White, N.C.; Siddeley, G.; editors). International Journal of Geochemical Exploration 36: 197-232.

Camus, F. 2003. Geología de los sistemas porfíricos en los Andes de Chile. Servicio Nacional de Geología y Minería: 267 p. Santiago.

Camus, F. 2011. E1 Potencial Minero de la Cordillera de la Costa de Chile para la Exploración, Latin American Exploration Forum 2011, Power Point Presentation: 25 slides. Santiago.

Camus, F. 2018. Yacimientos Epitermales de Alta y Baja Sulfidización de Chile. Seminario de Yacimientos Epitermales, El Oro y Plata de América. Colegio de Geólogos de Chile, Power Point: 54 slides.

Camus, F.; Duhalde, M.A. 1982. Geología de los Yacimientos Hidrotermales de Oro en Chile. Revista Geológica de Chile 17: 47-70. doi: 10.5027/andgeoV9n3-a04. 
Camus, F.; Skewes, M.A. 1991. The Faride epithermal silver-gold deposit, Antofagasta region, Chile. Economic Geology 86: 1222-1237.

Camus, F.; Boric, R.; Skewes, M.A.; Castelli, J.C.; Reichard, E.; Mestre, A. 1991. Geologic, Structural, and Fluid Inclusions Studies of El Bronce Epithermal Vein System, Petorca, Central Chile. Economic Geology 86: $1317-1345$

Castellón, R. 2017. Geología del yacimiento Panulcillo, Características Geoquímicas y Control Estructural de Cuerpos Mineralizados. Tesis para optar al grado de Magister en Ciencias de la Ingeniería (Unpublished), Pontificia Universidad Católica de Chile, Escuela de Ingeniería: $190 \mathrm{p}$.

Charrier, R.; Pinto, L.; Rodríguez, M. 2007. Tectonostratigraphic evolution of the Andean Orogen in Chile. In The Geology of Chile (Moreno, T.; Gibbons, W.; editors). The Geological Society of London: 21-114.

Charrier, R.; Ramos, V.; Tapia, F.; Sagripanti, L. 2014. Tectono-stratigraphic evolution of the Andean orogeny between 31 and $37^{\circ} \mathrm{S}$ (Chile and Western Argentina). Geological Society, London, Special Publications 399: 49 p.

Charrier, R.; Muñoz, M.; Farías, M. 2015. Cenozoic magmatism and deformation in the northern and central Chilean Andes: differing paths in the construction of the modern orogeny. In Congreso Geológico Chileno, No. 14: 121-124. La Serena.

Chen, H.; Cooke, D.R.; Baker, M.J. 2013. Mesozoic Iron Oxide Copper-Gold Mineralization in the Central Andes and the Gondwana Supercontinent Breakup. Economic Geology 108: 37-44.

Churata, E.; Vergara, R.; Villegas, P.; Toro, J. 2019. Mocha Porphyry Copper Deposit: An Update. SEG South American Conference: Sierra to Craton: Abstracts: 3 p.

Cochilco. 2010. Copper and Gold Mining Investment in Chile. Chilean Copper Commission-Research and Policy Planning Department: 24 p. Santiago.

Coira, B.; Davidson, J.; Mpodozis, C.; Ramos, V.A. 1982. Tectonic and magmatic evolution of the Andes of northern Argentina and Chile: Earth-Science Reviews 18: 303-332.

Colley, H.; Treolar, P.J.; Díaz, F. 1989. Gold-silver mineralization in the El Salvador region, northern Chile: Economic Geology Monograph 6: 208-217.

Coloma, F.; Valin, X.; Oliveros, V.; Vásquez, P.; Creixell, C.; Salazar, E.; Ducea, M.N. 2017. Geochemistry of Permian to Triassic igneous rocks from northern Chile $\left(28^{\circ}-30^{\circ} 15^{\prime} \mathrm{S}\right)$ : Implications on the dynamics of the
proto-Andean margin, Andean Geology 44 (2): $147-$ 178. doi: 10.5027/andgeoV44n2-a03.

Cuadra, W.; Dunkerley, P.M. 1991. A History of Gold in Chile. Economic Geology 86: 1155-1173.

Cuitiño, L.; Díaz, S.; Puig, A. 1988. Aspectos de la mineralogía, geoquímica y geotermometría de los yacimientos epitermales Guanaco y Cachinal de la Sierra, Antofagasta, Chile. In Congreso Geológico Chileno, No. 5, Actas: B273-B278. Santiago.

Dalziel, I.W.D. 1986. Collision and Cordilleran orogenesis: An Andean perspective: Geological Society of London Special Publication 2: 389-404.

Davidson, J.; Mpodozis, C. 1991. Regional geologic setting of epithermal gold deposits, Chile: Economic Geology 86: 1174-1186.

Deckart, K.; Hervé, F.; Fanning, M.; Ramírez, V.; Calderón, M.; Godoy, E. 2014. U-Pb Geochronology and Hf-O Isotopes of zircons from the Pennsylvanian Coastal Batholith, South-Central Chile, Andean Geology 41 (1): 49-82. doi: 10.5027/andgeoV41n1-a03.

Díaz-Alvarado, J.; Galaz, G.; Oliveros, V.; Creixell. C.; Calderón, M. 2019. Fragments of the late Paleozoic accretionary complex in central and Northern Chile: Similarities and differences as a key to decipher the complexity of the late Paleozoic to Triassic early Andean events. In Andean tectonics (Horton, B.K.; Folguera, A.; editors): 509-530.

Easdon, M. 2010. Technical Report on the Cerro Maricunga Gold Project, Region III, Chile. Atacama Pacific Gold Corporation: $69 \mathrm{p}$.

Eggert, E.; Kasaneva, S. 1995. San Cristobal gold district, Antofagasta, Chile: Pacrim Congress 95. The Australian Institute of Mining and Metallurgy Publication Series 9 (95): 197-202.

Equus Mining Ltd. 2017. Los Domos Epithermal Project. Annual General Meeting Presentation: 21 p.

Forsythe, R.D.; Kent, D.V.; Mpodozis, C.; Davidson, J. 1987. Paleomagnetism of Permian and Triassic rocks, central Chilean Andes. In Gondwana Six: Structure, tectonics and geophysics (Mckenzie, G.D.; editor) Geophysical Monograph 40: 241-252. Washington.

Frikken, P.; Cooke, D.; Walshe, J.; Archibald, D.; Skarmeta, J.; Serrano, L.; Vargas, R. 2005. Mineralogical and Isotopic Zonation in the Sur-Sur Tourmaline Breccia Río Blanco-Los Bronces Cu-Mo Deposit, Chile: Implication for ore genesis. Economic Geology 100 (5): 935-961.

Gamonal, S.; Bissig,T.; Fletcher, D.; Schroer, G.; den Boer, D.; Jemielita, R. 2015. Oligocene to Miocene volcanic and hydrothermal history and revised early to 
middle Miocene Ag-Au mineralization ages of the $\mathrm{La}$ Coipa district, Maricunga belt. In Congreso Geológico Chileno, No. 14, Actas: 4 p. La Serena.

Gamonal, S.; Bissig, T. 2019. Metallogenic Evolution of the Maricunga Belt and Adjacent Arc Segments: A Case for tectonic Domains Controlling Distribution of Epithermal versus Porphyry Deposits. SEG South American Conference: Sierra to Craton: Abstracts: 3 p.

Gardeweg, M.; Ramírez, C. 1984. Volcanismo del Cenozoico Superior del Altiplano Chileno $\left(18^{\circ}-28^{\circ} \mathrm{S}\right)$, en Seminario Actualización de la Geología de Chile, Apuntes, Sernageomin: E1-31.

Garrido, I.; 2013. Dominga Project, VI International Exploration Forum CESCO 2013, Santiago. Andes Iron Power Point Presentation: 13 slides.

Garofalo, P. 2009. Physical-chemical properties of the hydrothermal ore fluid in the Faride epithermal deposit (Antofagasta Region, Chile) from a preliminary set of high resolution fluid inclusion. GEOACTA, Special Publication 2: 87-95.

Greiner, G.1991. Características y Distribución de los Placeres Auríferos de Chile. In Gisements Alluviaux d'Or: 14 p. La Paz.

Goldcorp. 2017. Fact Sheet -50/50 Joint venture in Maricunga District. http://Goldcorp.com; (Last visit May, 2020).

Gröpper, J. 2011. Franjas Metalogénicas de Edad Jurásica y Cretácica en la Cordillera de la Costa de Chile Central, entre $32^{\circ}$ y $35^{\circ} 20^{\prime}$ de latitud Sur. Tesis (Unpublished), Departamento de Geología, Universidad de Chile: 132 p.

Gröpper, H.; Calvo, M.; Crespo, H.; Bisso, C.R.; Cuadra, W.A.; Dunkerley, P.M.; Aguirre, E. 1991. The epithermal gold-silver deposit of Choquelimpie, northern Chile: Economic Geology 86: 1206-1221.

Henríquez, F.; Skewes, M.A.; Vergara, L.; Aguirre, H.; Villagrán, J. 1991. Yacimientos Mesotermales de Oro en las Regiones de Atacama y Coquimbo, Chile. In Congreso Geológico Chileno, No. 6, Resúmenes Ampliados: 155-158.

Herrera, V.; Garmendia, P.; Pizarro, R. 2008. Proyecto Diego de Almagro: Geología y mineralización tipo IOCG, Región de Atacama, Norte de Chile. In Congreso Latinoamericano de Geología, No. 13, Actas 2: 1-6. Lima.

Herrera, S.; Pinto, L.; Deckart, K.; Cortés, J.; Valenzuela, J. 2017. Cenozoic tectonostratigraphic evolution and architecture of the Central Andes in northern Chile based on the Aquine region, Western Cordillera (19-19³0' S). Andean Geology 44 (2): 87-122. doi: 10.5027/andgeoV44n2-a01.

Hervé, F.; Faúndez, V.; Calderón, M.; Massone, H.; Willner, A. 2007. Metamorphic and plutonic basement complexes. In The Geology of Chile (Moreno, T.; Gibbons, W.; editors). The Geological Society of London: 5-19.

Hunt, J.; Bratt, J.; Marquardt, J.C. 1983. Quebrada Blanca, Chile: an enriched porphyry copper-deposit, Mining Engineering 35: 636-644.

Irarrázaval, V. 2011. Proyecto West Wall San Felipe, Chile, CESCO, Power Point presentation: 13 slides.

Iriarte, S. 1993. Control estructural de la mineralización vetiformes en la mina Faride y su relación con el distrito de Sierra Gorda, región de Antofagasta, Chile. Master of Science Thesis (Unpublished), Universidad de Chile: 185 p. Santiago.

Jannas, R.R.; Beane, R.E.; Ahler, B.A.; Brosnahau, D.R. 1990. Gold and copper mineralization at the El Indio deposit, Chile: Journal of Geochemical Exploration 36: 233-266.

Jannas, R.R.; Bowers, T.S.; Petersen, U.; Beane, R. 1999. High-Sulfidation Deposit Types in the El Indio District, Chile. In Geology and Ore Deposits of the Central Andes (Skinner, B.J.; editor), Society of Economic Geologists, Special Publication, No. 7: 219-266.

Jara, C.; Miller, J.; Bardoux, M. 2019. Structural Evolution of the El Indio belt (Chile-Argentina): Mineralisation Events. SEG South American Conference: Sierra to Craton, Abstracts: 3 p.

Jordan, T.E.; Isaacks, B.L.; Allmendinger, R.W.; Brewer, J.A.; Ramos, V.A.; Ando, C.J. 1983. Andean tectonics related to geometry of subducted Nazca plate: Geological Society of America Bulletin 94: 241-361.

Jordan, T.E.; Gardeweg, M. 1988. Tectonic evolution of the late Cenozoic central Andes mountains, $\left(20^{\circ}-33^{\circ} \mathrm{S}\right)$. In The evolution of the Pacific Ocean margins (BenAvraham, Z.; editor). Oxford University Press: 193207. New York.

Jovic, S.; Guido, D.; Páez, G.; Galina, M. 2015. Marco tectónico y estructural del depósito epitermal de alta sulfuración El Guanaco. In Congreso Geológico Chileno, No. 14, Actas: 4 p. La Serena.

Kay, S.M.; Maksaev, V.; Moscoso, R.; Mpodozis, C.; Nasi, C. 1987. Probing the Andean lithosphere: Mid-late Tertiary magmatism in Chile $\left(29^{\circ}-30.5^{\circ} \mathrm{S}\right)$ over the zone of sub horizontal subduction. Journal of Geophysical Research 92: 6173-618

Kay, S.M.; Mpodozis, C.; Coira, B. 1999. Neogene Magmatism, Tectonism, and Mineral Deposits of the Central Andes. In Geology and Ore Deposits of the Central Andes (Skinner, B.J.; editor). Society of Economic Geologists, Special Publication, No. 7: 27-59. 
Kay, S.M.; Godoy, E. 2005. Episodic arc migration, crustal thickening, subduction erosion, and magmatism in the south-central Andes, Geological Society of America Bulletin 117 (1-2): 67-88.

Kingsgate Consolidated Ltd. 2016. Nueva Esperanza Mineral Resource Update, Press Release: 20 p.

Kojima, S. 1999. Some Aspects Regarding the tectonic Setting of High- and Low-sulfidation Epithermal Gold of Chile. Resource Geology 49 (3): 175-181.

Kojima, S.; Campos, E. 2011. An Overview of Chilean Economic Deposits. SGA News 29: 8 p.

Lagos, R. 2010. Exploración minera del Proyecto Chimberos Este, Distrito Esperanza, Región de Atacama, Chile. Memoria para optar al Título de Geólogo (Unpublished), Departamento de Geología, Universidad de Chile: $101 \mathrm{p}$.

Lambert, R.; Gow, N.; Hampton, P.; Gochnour, L. 2012. Technical Report on the El Morro Project, Region III, Chile, RPA. New Gold Inc.: 167 p.

Lewis, J.; San Martin, A.; Gowans, R.; Shoemaker, S. 2011. Technical Report on the Results of the Pre-feasibility Study of the Dorado Deposits, Volcan Gold Project, Region III, Chile. MICON International Ltd.: 174 p.

Llaumett, C. 1980. Antecedentes sobre producción, recursos, y expectativas de la minería del oro en Chile. Revista Minerales 35 (150): 9-20.

Llaumett, C. 2009. Proyecto Inca de Oro Sur, Geología, Mineralización y Evaluación de Recursos, III Región Chile. Unpublished report: $44 \mathrm{p}$.

Llaumett, C.; Marín, C.; Marquardt, C.; Olcay, L.; Reyes, E. 1975. El yacimiento cuprífero Andacollo. Revista Minerales 30 (130): 4-8.

López, G.; Hitzman, M.; Nelson, E. 2014. Alteration patterns and structural controls of the El Espino IOCG mining district, Chile. Mineralium Deposita 49 (2): 235-259.

López, L.; Ristorcelli, S. 2011. Technical Report for the Sierra Gorda Project, Chile; an NI 43-101 Technical Report prepared for Quadra Mining Ltd. by Pincock, Allen and Holt: 240 p.

McGregor, J.; Brady, B. 2016. An Updated Technical Report on the Pimenton Mine, the surrounding Pimenton Property, and the near Tordillo Property in Central Chile for Compañía Minera Pimenton. Internal Report: 103 p.

Maksaev, V. 1990. Metallogeny, Geological Evolution, and Thermochronology of the Chilean Andes, between latitudes $21^{\circ}$ and $26^{\circ}$ South, and the Origin of Major Porphyry Copper Deposits, Ph.D. Thesis (Unpublished), Dalhousie University: 554 p. Halifax, Nova Scotia.
Maksaev, V. 2005. Skarns of Chile. In World skarn deposits (Meinert, L.D.; Dipple, G.M.; Nicolescu, S.; editors). Economic Geology $100^{\text {th }}$ Anniversary Volume 19052005: 299-336.

Maksaev, V.; Moscoso, R.; Mpodozis, C.; Nasi, C. 1984. Las unidades volcánicas y plutónicas del Cenozoico Superior en la Alta Cordillera del Norte Chico $\left(29^{\circ}-31^{\circ} \mathrm{S}\right)$. Geología, alteración hidrotermal y mineralización. Revista Geológica de Chile 21: 11-51. doi: 10.5027/ andgeoV11n1-a02.

Maksaev, V.; Zentilli, M. 1988. Marco metalogénico regional de los depósitos de tipo pórfido cuprífero del Norte Grande de Chile. In Congreso Geológico Chileno, No. 5, Tomo I: B181-B212.

Maksaev, V.; Townley, B.; Palacios, C.; Camus, F. 2007. Metallic ore deposits. In The Geology of Chile (Moreno, T.; Gibbons, W.; editors). The Geological Society of London: 179-199. London.

McKee, E.H.; Noble, D.C. 1990. Cenozoic tectonic events, magmatic pulses, and base and precious metal mineralization in the central Andes: Earth Science, Ser. Circum-Pacific Council for Energy and Mineral Resources (11): 189-194.

Marquardt, J.C.; Rojas, O.; Puig, A.; Valdés, R. 1994. El Distrito Anillo, un sistema hidrotermal alto tipo pórfido de oro del Eoceno, en la depresión central de la II Región Chile. In Congreso Geológico Chileno, No 7, Actas (2): 855-859. Concepción.

Marquardt, M.; Cembrano, J.; Bissig, T.; Vázquez, C. 2015. Mid Cretaceous Cu-Au-(Mo) mineralization in the Vallenar District: new Re-Os age constraints from Productora deposit, Northern Chile, Congreso Geológico Chileno, No. 14: 4 p. La Serena.

Marschik, R.; Fontboté, L1.; Chiaradia, M. 1997. Cu (-Fe)-Au Mineralization in the Punta del Cobre Belt, Chile. In Congreso Geológico Chileno, No. 8, Actas 2: 1059-1062. Antofagasta.

Marschik, R.; Leveille, R.A.; Martin, W. 2000. La Candelaria and the Punta del Cobre district, Chile. Early Cretaceous iron oxide $\mathrm{Cu}-\mathrm{Au}$ (-Zn-Ag) mineralization. In Hydrothermal iron oxide copper-gold and related deposits: A global perspective (Porter, T.M.; editor). Australian Mineral Foundation: 163-175. Adelaide.

Marsh, T.M.; Einaudi, M.T.; McWilliams, M. 1997. ${ }^{40} \mathrm{Ar} /{ }^{39} \mathrm{Ar}$ geochronology of $\mathrm{Cu}-\mathrm{Au}$ and $\mathrm{Au}-\mathrm{Ag}$ mineralization in the Potrerillos district, Chile. Economic Geology 97: 784-806.

Miller, J.F.; Harris, N.B.W. 1989. Evolution of continental crust in the Central Andes: constraints from $\mathrm{Nd}$ isotope systematics. Geology 17: 615-617. 
Moncada, D.; De Pascale, G.; Reich, M.; Barra, F.; Morata, D.; Calderón, C.; González, J.; González, H.; Mundaca, P. 2015. Fluids in the Alhué gold mining District, Chile. In Congreso Geológico Chileno, No. 14, Actas: 4 p. La Serena.

Morel, R. 2009. Clasificación y distribución de depósitos de $\mathrm{Cu}-\mathrm{Fe}(\mathrm{Au}, \mathrm{Ag})$ en el cinturón jurásico-cretácico del norte de Chile ( $25^{\circ}-31^{\circ}$ L.S.): un enfoque para la exploración de recursos de $\mathrm{Cu}$. In Congreso Geológico Chileno, No. 12: 4 p. Santiago.

Mpodozis, C.; Ramos, V.A. 1990. The Andes of Chile and Argentina. Circum-Pacific Council Energy Mineral Resources, Earth and Science Series 11: 59-90.

Mpodozis, C.; Kay, S. 1990. Provincias magmáticas ácidas y evolución tectónica de Gondwana: Andes Chilenos (28-33 S). Revista Geológica de Chile 17 (2): 153 180. doi: 10.5027/andgeoV17n2-a03.

Mpodozis, C.; Cornejo, P. 2019. Evolving Active Margin Magmatism, Tectonics, and Mineralization in the Northern Chilean Andes: A Short Review. SEG South American Conference: Sierra to Craton: Abstracts: $2 \mathrm{p}$.

Muntean, J.L.; Einaudi, M.T. 2001. Porphry-Epithermal Transition: Maricunga Belt, Northern Chile. Economic Geology 96: 743-772.

Naranjo, J.; Hevia, F.; Creixell, C. 2019. Volcano-Tectonic Paleo Environmental Evolution of the Southern Maricunga Belt. SEG South American Conference: Sierra to Craton: Abstracts: 2 p.

Narváez, P.; Aguirre, C. 2015. Distrito Minero San Antonio, un depósito skarn-IOCG de la Región de Coquimbo. In Congreso Geológico Chileno, No.14, Actas: 440443. La Serena.

Nasi, C.; Mpodozis, C.; Cornejo, P.; Moscoso, R.; Maksaev, V. 1985. El batolito Elqui-Limarí (Paleozoico superiorTriásico): Características petrográficas, geoquímicas y significado tectónico. Revista Geológica de Chile 25-26: 77-111. doi: 10.5027/andgeoV12n2-3-a06.

Nasi, C.; Moscoso, R.; Maksaev, V. 1990. Hoja Guanta. Regiones de Atacama y Coquimbo.Servicio Nacional de Geología y Minería, Carta Geológica de Chile, Serie Geología Básica 67: 140 p., 1 mapa escala $1: 250.000$.

Natural Resources Holding. 2013. Global Gold Mines \& Deposits 2013 Ranking. NRH Research: 40 p.

NGEX. 2016. Project Constellation, Power Point Presentation: 16 slides.

Oliveros, V.; Morata, D.; Aguirre, L.; Féraud, G.; Fornari, M. 2007. Jurassic to Early Cretaceous subduction-related magmatism in the Coastal Cordillera of northern Chile $\left(18^{\circ} 30^{\prime}-24^{\circ} \mathrm{S}\right)$ : geochemistry and petrogenesis. Revista
Geológica de Chile 34 (2): 209-232. doi: 10.5027/ andgeoV34n2-a03.

Oliveros, V.; Vásquez, P.; Creixell, C.; Lucassen, F.; Ducea, M.H.; Ciocca, I.; González, J.; Espinoza, M.; Salazar, E.; Coloma, F.; Kasemann, S.A. 2020. Lithospheric evolution of the Pre- and Early Andean convergent margin, Chile. Gondwana Research 80: 202-227. doi: 10.1016/j.gr.2019.11.002.

Oviedo, L.; Fuster, N.; Tschischow, N.; Ribba, L.; Zuccone, A.; Grez, E.; Aguilar, A. 1991. General geology of La Coipa precious metal deposit, Atacama, Chile. Economic Geology 86: 1287-1300.

Oyarzún, R.; Ortega, L.; Sierra, J.; Lunar, R.; Oyarzún, J. 1996. The Manto-Type Gold Deposits of Andacollo (Chile) Revisited: A Model Based on Fluid Inclusion and Geologic Evidence, Economic Geology 9: 1298-1309.

Parada, M.A.; López-Escobar, L.; Oliveros, V.; Fuentes, F.; Morata, D.; Calderón, M.; Aguirre, L.; Féraud, G.; Espinoza, F.; Moreno, H.; Figueroa, O.; Muñoz, J.; Bravo, R.; Troncoso, R.; Stern, C.R. 2007. Andean Magmatism. In The Geology of Chile (Moreno, T.; Gibbons, W.; editors). The Geological Society of London: 115-146. London.

Pardo, R. 2006. Proyecto Pimentón, Región de ValparaísoChile. Informe Final, Río Tinto Mining and Exploration Ltd.: 31 p.

Pardo-Casas, F.; Molnar, P. 1987. Relative motion of the Nazca (Farellón) and South American plates since late Cretaceous time. Tectonics 6: 233-248.

Pegasus Gold Inc. 1997. Pullalli Project in 1996 Annual Report: 63 p.

Perelló, J.; Cabello, J. 1989. Pórfidos Cupríferos ricos en Oro: una revisión. Revista Geológica de Chile 16 (1):73-92. doi: 10.5027/andgeoV16n1-a05.

Perelló, J.; Urzúa, F.; Cabello, J.; Ortiz, F. 1996. Clustered, gold-bearing Oligocene Porphyry Copper and Associated Epithermal Mineralization at La Fortuna, Vallenar Region, Northern Chile. Society of Economic Geologists Special Publication 5: 81-90.

Perelló, J.; Sillitoe, R.H.; Brockway, H.; Posso, H.; Mpodozis, C. 2009. Contiguous Porphyry Cu-Mo and $\mathrm{Cu}-\mathrm{Au}$ Mineralization at Los Pelambres, Central Chile. In Congreso Geológico Chileno, No. 12, Actas: 4 p. Santiago.

Perelló, J.; Muhr, R.; Mora, R.; Martinez, E.; Brockway, H.; Swaneck, T.; Artal, C.; Mpodozis, C.; Münchmeyer, C.; Clifford, J.; Acuña, E.; Valenzuela, D.; Argandoña, R. 2010. Wealth creation through Exploration in Mature Terrain: The Case History of the Centinela District, 
Northern Chile Porphyry Copper belt. Society of Economic Geologist Special Publication 15: 229-252

Pilger, R.H. 1984. Cenozoic plate kinematics, subduction and magmatism: South American Andes. Journal Geological Society of London 141: 293-802.

Poblete, J. 2011. Geology, Geochronology and Structural Reconstruction of the Cerro Bayo Epithermal District, Chilean Patagonia. M.Sc. Thesis (Unpublished), The University of British Columbia: 202 p. Vancouver.

Portigliati, C.; Emparan, C.; Vogel, S. 1988. Los agentes geológicos en la formación de placeres auríferos en el sur de Chile. In Congreso Geológico Chileno No. 5, Actas 1: A365-A383. Santiago.

Puig, A.; Díaz, S.; Cuitiño, L. 1988. Sistemas hidrotermales asociados a calderas en el arco volcánico Paleógeno de la región de Antofagasta, Chile: Distritos El Guanaco, Cachinal de la Sierra y El Soldado. Revista Geológica de Chile 15 (1): 57-82. doi: 10.5027/andgeoV15n1-a05.

Quintana, K. 2018. Caracterización Petrográfica y calcográfica de Zona Mina Este, Distrito Minero Alhué. Memoria de Título (Unpublished), Departamento de Ciencias de la Tierra, Universidad de Concepción: 37 p.

Ramos, V. 2010. The tectonic regime along the Andes: Present-day and Mesozoic regimes, Geological Journal 45: 2-25.

Ramos, V.; Folguera, A. 2016. Andean flat-slab subduction through time. In Ancient Orogens and Modern Analogues (Murphy, J.B.; Keppie, J.D.; Hynes, A.J.; editors). Geological Society of London, Special Publications 327: 31-54.

Reyes, M. 1991. The Andacollo strata-bound gold deposit, Chile and its position in a porphyry copper-gold system. Economic Geology 86: 1301-1316.

Richards, J.P.; López, G.P.; Zhu, J.; Creaser, R. A.; Locock, A.J.; Mumin, A.H. 2016. Contrasting tectonic settings and sulfur contents of magma associated with cretaceous porphyry $\mathrm{Cu}-\mathrm{Mo}-\mathrm{Au}$ and intrusion-related iron oxide $\mathrm{Cu}-\mathrm{Au}$ deposits, in northern Chile. Economic Geology 112: 295-318.

Rivano, S.; Sepúlveda, P. 1991. Hoja Illapel, Región de Coquimbo, escala 1:250.000. Servicio Nacional de Geología y Minería, Carta Geológica de Chile, Serie Geología Básica 69: 132 p., 1 mapa escala 1:250.000. Santiago.

Roeschman, C. 1979. El oro en el yacimiento de cobre El Salvador, Memoria de Título (Unpublished). Departamento de Geología, Universidad de Chile: 130 p. Santiago.

Ruiz, C.; Aguirre, L.; Corvalán, J.; Klohn, C.; Klohn, E.; Levi, B. 1965. Geología y Yacimientos Metalíferos de Chile, Distribución y Génesis de los Yacimientos Metalíferos Chilenos. Instituto de Investigaciones Geológicas: 302 p. Santiago.

Ruiz, C.; Peebles, F. 1988. Geología, Distribución y Génesis de los Yacimientos Metalíferos Chilenos. Editorial Universitaria: 334 p. Santiago.

Salazar, E.; Coloma, F. 2016.Geología del Área Cerros de Cantaritos -Laguna Chica, Región de Atacama. Servicio Nacional de Geología y Minería. Carta Geológica de Chile, Serie Geología Básica 181: 174 p., 1 mapa escala 1:100.000. Santiago.

SERNAGEOMIN (Servicio Nacional de Geología y Minería). 2020. Anuario de la Minería de Chile 2019, Servicio Nacional de Geología y Minería: 283 p. Santiago.

Sepúlveda, S.A.; Giambiagi, L.B.; Moreiras, S.M.; Pinto, L.; Tunik, M.; Hoke, G.D.; Farias, M. 2015. Geodynamic Processes in the Andes of Central Chile and Argentina: an introduction. Geological Society of London, Special Publications 399: 1-12.

Shatwell, D. 1999. Gold Resources of the Andean Region, David Shatwell Pty. Unpublished Report: 193 p.

Siddeley, G.; Araneda, R. 1990. Gold-silver occurrences of the El Indio belt, Chile. Circum-Pacific Council Energy Mineral Resources, Earth Science Series 11: 273-284.

Sillitoe, R.H. 1988. Epochs of intrusion-related copper mineralization in the Andes: Journal of South American Earth Sciences 1: 89-108.

Sillitoe, R.H. 1991. Gold Metallogeny of Chile: an Introduction. Economic Geology 86: 1187-1205.

Sillitoe, R.H. 1992. Gold and copper metallogeny of the central Andes, past, present and future exploration objectives. Economic Geology 87: 2205-2216.

Sillitoe, R.H. 1994. Models for Andean Copper Deposits. In Congreso Geológico Chileno, No. 7, Actas 2: p. 1618. Concepción.

Sillitoe, R.H. 1995. Exploration and Discovery of Baseand Precious-Metal Deposits in the Circum-Pacific Region During the Last 25 Years. Resource Geology Special Issue 19: 119 p.

Sillitoe, R.H. 1999. Styles of High-Sulphidation Gold, Silver and Copper Mineralisation in Porphyry and Epithermal Environments. PACRIM 99: 16 p. Bali.

Sillitoe, R.H. 2000. Exploration and Discovery of Baseand Precious-Metal Deposits in the Circum-Pacific Region During the Last 25 Years-A late 1990s Update. Resource Geology Special Issue 21: 65 p.

Sillitoe, R.H. 2003. Iron oxide-copper-gold deposits: An Andean view. Mineralium Deposita 38: 787-812.

Sillitoe, R.H. 2008. Major Gold Deposits and Belts of the North and South American Cordillera: Distribution, 
Tectonomagmatic Settings, and Metallogenic Considerations. Economic Geology 103: 663-687.

Sillitoe, R.H. 2010. Exploration and Discovery of Baseand Precious-Metal Deposits in the Circum-Pacific Region During the Last 25 Years-A 2010 Perspective. Resource Geology Special Issue 22: 139 p.

Sillitoe, R.H.; McKee, E.H.; Vila, T. 1991. Reconnaissance K-Ar geochronology of the Maricunga gold-silver belt, northern Chile: Economic Geology 86: 1261-1270.

Sillitoe, R.H.; Tolman, J.; Van Kerkvoort, G. 2013. Geology of the Caspiche porphyry Gold-Copper Deposit, Maricunga belt, Northern Chile. Economic Geology 108: 585-604.

Simón, A.; Larrondo, P.; Maycock, J.; Castillo, F.; Cabrera, R. 2010. Orosur Mining Inc., Pantanillo Norte Property. NI 43-101. Technical Report, Amec.: 140 p.

Singer, D.A.; Berger, V.I.; Moring, B.C. 2005. Porphyry copper deposits of the world-Database, map, and grade and tonnage models. U.S. Geological Survey. Open-file Report 2005-1060: 9 p.

Singer, D.A.; Berger, V.I.; Moring, B.C. 2008. Porphyry copper deposits of the world-Database, map, and grade and tonnage models. U.S. Geological Survey Open-file Report 2008-1155: 45 p.

Slater, D.; Hearne, J.; Kelley, R. 2012. CMD Gold Mine, Andacollo, Chile. Independent Technical Report: 240 p.

Stern, C. 2004. Active Andean volcanism: its geologic and tectonic setting. Revista Geológica de Chile 31 (2): 161-206.

Tassara, A.; Götze, H.J.; Schmidt, S.; Hackney, R. 2006. Three-dimensional density model of the Nazca plate and the Andean continental margin, Journal of Geophysicsical Research 111: B09404.

Teck Resources Limited. 2016. 2015 Annual Information Form, 117 p., http:/www.teck.com/media/Investorsaif_march_2016_T5.1.2.pdf. (Last visit 15/08/2019).

Thompson, J.F.H.; Gale, V.G.; Tosdal, R.; Wright, W.A. 2004. Characteristic and Formation of the Jerónimo Carbonate-Replacement Gold Deposit, Potrerillos District, Chile. Society of Economic Geologists Special Publication 11: 75-95.

Vidal, C.; Páez, G.; Galina, M.; Jovic, S.; Guido, M.; Moreira, P.; López, L. 2019. Distribution of the Hydrothermal Alteration at the Guanaco $\mathrm{Au}-\mathrm{Cu}$ District Mine, Northern Chile, SEG South American Conference: Sierra to Craton: Abstracts: 4 p.

Vila, T. 1991a. Epithermal silver-gold mineralization at the Esperanza area, Maricunga belt, High Andes of northern Chile. Revista Geológica de Chile 18 (1): 37-54.
Vila, T. 1991b. Precious Metals Mineralization Styles in the Maricunga Belt, High Andes of Northern Chile. In Congreso Geológico Chileno No.6, Resúmenes Expandidos: 153-154. Viña del Mar.

Vila, T.; Sillitoe, R.H. 1991. Gold-rich porphyry systems in the Maricunga belt, northern Chile. Economic Geology 86: 1238-1260.

Vivallo, W. 2009. Yacimientos de óxidos de Hierro-cobreoro en Chile. In Congreso Geológico Chileno, No. 12, Actas: 4 p. Santiago.

Vivallo, W.; Díaz, A.; Jorquera, R. 2008. Yacimientos Metalíferos de la Región de Atacama. Servicio Nacional de Geología y Minería. Carta Geológica de Chile, Serie Recursos Minerales y Energéticos 27: 75 p.

Vivallo, W.; Díaz, A.; Jorquera, R. 2009. Provincias Metalogénicas en la Región de Atacama, Chile. In Congreso Geológico Chileno, No. 12, Actas: 4 p. Santiago.

Warren, I.; Archibald, D.; Simmons, S.F. 2008. Geochronology of epithermal Au-Ag mineralization, magmatic-hydrothermal alteration and supergene weathering in the El Peñón district, northern Chile. Economic Geology 103 (4): 851-864.

Wheeler, D.E. 1991. Coeur d'Alene Mines-a commitment to growth (abs.): World Gold '91, The Australian Institute of Mining, Metallurgy and Exploration (AusIIM)Society for Mining, metallurgy and Exploration(SME) Joint Conference, $2^{\text {nd }}$, Cairns, Queensland: 285-286.

Willner, A.P.; Richter, P.P.; Ring, U. 2009. Structural overprint of a late Paleozoic accretionary system in north-central Chile $\left(34^{\circ}-35^{\circ} \mathrm{S}\right)$ during post-accretional deformation, Andean Geology 36 (1): 17-36.

Yamana Gold. 2018. Resource Updates for La Pepa, Jerónimo and Amancaya, News Release: 5 p. Toronto.

Zentilli, M.; Muljia, T.; Walker, J.A.; Maksaev, V. 1988. Effects of hydrothermal alteration in the distribution of gold in Miocene rocks of Copiapó Volcanic Complex, Chile. Revista Comunicaciones 39: p. 80.

Zentilli, M.; Stark, A.; Reynolds, P.H.; Mulja, T.; Walker, J.A.; Ulricksen, C.E. 1991. Native sulphur deposits as the crown of epithermal systems? Isotopic and geochronological data on Volcán Copiapó Complex, Maricunga, northern Chile. In Congreso Geológico de Chile, No.6. Actas Resúmenes Expandidos: 616-620. Viña del Mar.

Zuluaga, I. 2018. Geología Distrito El Peñón, II Región, Yamana Gold, Seminario yacimientos Epitermales de Au-Ag de América, Power Point Presentation: 86 slides. 